\title{
Foreword to Pre-Print
}

This pre-print details the geochemistry across a newly discovered extraordinarily wellpreserved stratigraphic section of the Permian-Triassic boundary in Utah. The attached manuscript features a comprehensive geochemical dataset from northeastern Utah, assembled from a unique and remarkable 9-meter section of rock in Sheep Creek Valley. The findings include a large-scale carbon isotopic excursion across the event, indicative of high atmospheric carbon dioxide, as well as a dramatic reduction in the deposition of calcium carbonate due to ocean acidification at the boundary layer. This study further documents an elevated mercuryspike, as well as observed elevated lead, zinc and strontium content.

This evidence suggests large amounts of naturally occurring emissions of coal combustion at the Permian-Triassic boundary, likely caused by the large scale volcanic eruptions of the coeval Siberian Traps. The resulting global changes associated with the abrupt enrichment of the atmosphere in carbon dioxide was the major contributor to the mass extinction event.

This is the first study to examine barium content across the Permian-Triassic boundary, and it provides evidence that upwelling of methane hydrate in the oceans followed the initial acidification event. Ocean anoxia (absence of oxygen) is suggested by the unusual deposition of pyrite within the shallow marine waters of the once coastal sediments of northeastern Utah. Precession orbital geochemical variation is observed in the stratigraphic section allowing a finer temporal resolution beyond any previously published section. Together, this dataset gives a unique picture of an ancient cataclysm that altered life on Earth. This study is a cautionary tell of what can happen if we do not heed the warnings of the geological past.

In Payne and Clapham's 2012 review of the Permian-Triassic boundary they suggested "the end-Permian extinction may serve as an important ancient analog for the twenty-first century...." The results of this study amplify that statement, as evidence gathered in this study suggest that large emissions of burning coal and other hydrocarbons during the Siberian Trap volcanic event was largely responsible for Earth's largest mass extinction 252 million years ago. A greater understanding of this ancient event may be the key in helping researchers forecast changes facing the Earth today.

If you are interested in this subject, notice any errors in the manuscript, or simply wish to contact the author, feel free to email me at benjamin.burger(at)usu.edu.

In Regards,

Benjamin J. Burger

Associate Professor of Geology

Utah State University - Uintah Basin Campus

Vernal, Utah 


\title{
What caused Earth's largest mass extinction event? New evidence from the Permian-Triassic boundary in northeastern Utah
}

\author{
Author: Benjamin J. Burger ${ }^{1 *}$
}

\begin{abstract}
Affiliations:
${ }^{1}$ Department of Geology, Utah State University Uintah Basin Campus, 320 North Aggie Blvd. Vernal, Utah USA 84078
\end{abstract}

*Correspondence to: benjamin.burger@usu.edu

\begin{abstract}
The discovery of a Permian-Triassic boundary section in northeastern Utah reveals a detailed record of events that led to one of the greatest mass extinctions on the planet. From $83 \%$ to $97 \%$ of the species living on the planet went extinct during this relatively short interval of geological time, which defines the major geological boundary between the Paleozoic and Mesozoic Eras. The cause and resulting sequence of events that led to this extinction have puzzled geologists for years. A new stratigraphic section in Utah provides details enabling the reconstruction of the events that led to this mass extinction. Geochemical analysis of the section demonstrates a significant drop in carbonate and total organic carbon, and a delayed occurrence of pyrite framboids. Carbon isotope ratios $\left(\delta^{13} \mathrm{C}\right)$ show a negative excursion in carbonate with ratios dropping from $2.585 \%$ o to $-3.627 \%$. Elevated mercury is present at the boundary with a 4 fold increase from background levels. The boundary layer shows elevated zinc, lead, strontium, and nickel, but not at high enough levels to indicate a volcanic ash source. There is no evidence in concentrations of siderophile and chalcophile elements for an extraterrestrial impact. The stratigraphic section in Utah supports the theory of a massive release of carbon dioxide, resulting in the acidification of the oceans. High levels of mercury, as well as elevated levels of zinc and lead, implicate a coal source triggered by the contemporary Siberian Traps sill complex. The delay of enriched sulfur and barium content in the stratigraphic record indicates an anoxic ocean and upwelling of methane hydrates from depth. Further study of this stratigraphic section will aid our understanding of the global impact these catastrophic events had on life and hopefully prevent it from happening again.
\end{abstract}




\section{Introduction}

In 2002, Alvarez and O’Connor (2002) challenged geologists working in the American Southwest to locate the Permian-Triassic boundary. The boundary, however, proved elusive, as many of the studied outcrops in western Utah and eastern Nevada demonstrated unconformities resulting in a hiatus across the boundary interval (Paull \& Paull, 1982). In the Great Basin of western Utah, the boundary is often represented by a conglomerate atop erosional Permian rock layers. Sperling and Ingle (2006) were the first to document a continuous Permian-Triassic section based solely on carbon isotopes in northern Nevada in the deeper marine facies of the Quinn River Formation. And study of late Permian and early Triassic rocks in southeastern Idaho has also suggested a possible boundary section (Wignall \& Hallam, 1992), although often these sections have been interpreted as drowning unconformities due to rapid changes in sea level (Paull \& Paull, 1994) or faulted by subsequent tectonic activity (Paull \& Paull, 1982). Rocks in southeastern Idaho and extending to southcentral Utah preserve remarkable early Triassic (Smithian) marine faunas (Schubert \& Bottjer, 1995; Fraiser \& Bottjer, 2007; Brayard et al. 2017), which record the biological recovery following the mass extinction event. However, well preserved shallow marine Permian-Triassic boundary sections along the western coastline of Pangea have been elusive until now. This study details observations across a newly discovered Permian-Triassic boundary stratigraphic section in northeastern Utah. The newly discovered section on the western coastline of Pangea offers a new regional look at the changing chemistry of the Panthalassic Ocean. This is the first section of the boundary from the shallow-marine western coastline of Pangea at an equatorial paleolatitude. 
The newly discovered boundary section is located along the northern flank of the Uinta Mountains in northeastern Utah along Sheep Creek Valley, which preserves a thick sequence of late Permian and early Triassic rock layers (Fig. 1). The local area has previously received little attention, despite the well exposed outcrops of the earliest Triassic (Gresbachian) Dinwoody Formation, and latest Permian Park City Formation. The new Utah stratigraphic section across the Permian-Triassic boundary is compared geochemically with other stratigraphic sections, particularly those from the Global Boundary Stratotype Section and Point (GSSP) in Meishan, South China (Hongful et al. 2001).

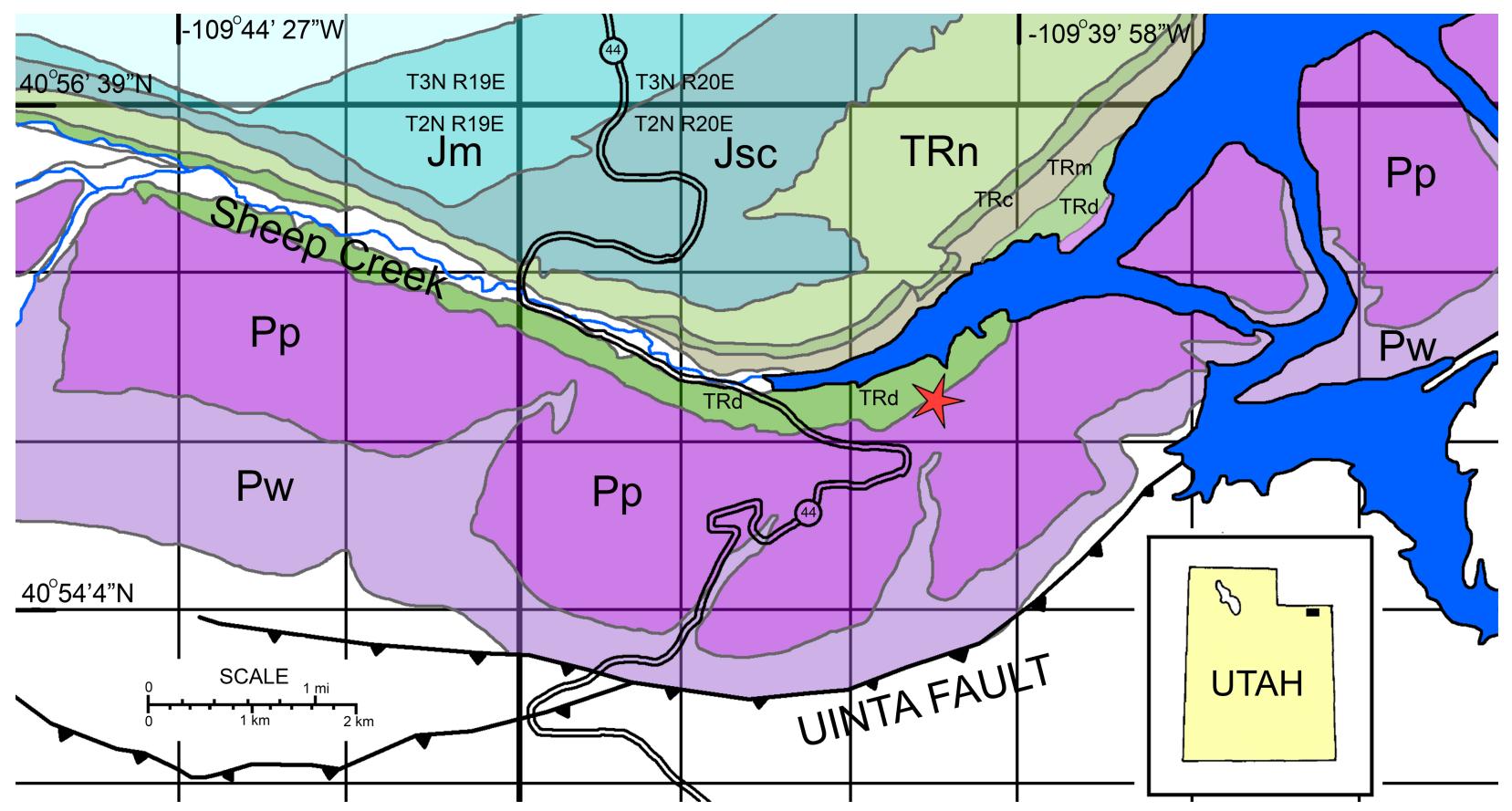

Fig. 1. Simplified geological map of Sheep Creek Valley showing location of the Permian-

Triassic stratigraphic section. (Pw), Permian Weber Formation. (Pp), Permian Park City Formation. (TRd), Triassic Dinwoody Formation. (TRm), Triassic Moenkopi Formation. (TRc), Triassic Chinle Formation. (TRn), Triassic Nugget Formation. (Jsc), Jurassic Stump/Curtis Formation. (Jm), Jurassic Morrison Formation. 
Geochemical signals documented from other sections across the Permian-Triassic Boundary provide a method for the identification of the boundary within the localized section in Utah. These observations include: 1) a significant drop in Total Organic Carbon (TOC) due to loss of bio-productivity (Korte et al. 2004; Krull et al. 2004; Berner 2006; Sanei et al. 2012), but not observed in high-latitude sections in New Zealand and Canada (Krull et al. 2000; Schoepfer et al. 2012), and 2) a negative carbon isotope excursion, with carbonate ratios $\left(\delta^{13} \mathrm{C}\right)$ dropping from ranges between 4.0 and 3.0\% VPDB to between -1.0 and -3.0\% VPDB during the Permian-Triassic extinction event (Jin et al. 2000; Riccardi et al. 2007; Sun et al. 2012). Other observations of the Permian-Triassic boundary include 3) the presence of pyrite framboids in marine sediments indicating an anoxic event that was remarkably shallow and sudden during the interval (Wignall \& Hallam, 1992; Wignall \& Twitchett, 2002; Wignall et al. 2005; Shen et al. 2007; Kakuwa, 2008; Bond \& Wignall, 2010; Brennecka et al. 2011; Schoepfer et al. 2012;

Schoepfer et al. 2013; Liao et al. 2017), and 4) a dramatic decrease in carbonate deposition indicating increasing acidity in the world's ocean, and shallowing of the carbonate compensation depth (CCD; Kakuwa, 1996; Kershaw et al. 1999; Payne et al. 2007). More recently discovered indicators include 5) a 3-fold increase in mercury $(\mathrm{Hg})$ restricted to the boundary layer (Sanei et al. 2012; Grasby et al. 2016); and 6) a 3 to 10 -fold increase in nickel (Ni) and zinc ( $\mathrm{Zn}$ ) within the boundary layer (Liu et al. 2017; Rampino et al. 2017), which is interpreted as a result of volcanic ash fallout from the Siberian Traps large igneous province eruptions (Le Vaillant et al. 2017).

\section{Geological Setting}

Bounded by the Permian Park City Limestone and Triassic Nugget Sandstone, the Sheep Creek Valley is a short valley formed by a tributary of the Green River, which runs along the bedding 
plane of the softer shale and mudstone rock layers, in the northeastern corner of Utah near the town of Manila (Fig. 1). The valley borders the Flaming Gorge Reservoir on the north side of the Uinta Mountain Range, with rock beds dipping 19 to 30 degrees toward the north and strikes bearing east-west, parallel to the axis of the mountain range. The Flaming Gorge Reservoir forms a freshwater flooded embayment into the valley downstream toward the east, while the upslope western end of the Sheep Creek Valley narrows into the Sheep Creek Canyon Geological Area managed by the U.S. Forest Service (Sprinkel et al. 2000). Paleozoic formations in the valley include the Weber Sandstone and Park City Limestone, while the Mesozoic formations are represented by the Triassic Dinwoody, Moenkopi, Chinle and Nugget formations, with Jurassic and Cretaceous units exposed toward the north (Fig. 1).

Based on biostratigraphic ranges of conodonts and brachiopods from outcrops in the Great Basin of Nevada, Idaho and western Utah, the Park City Limestone is regarded as late Permian in age (Guadalupian Age; Wardlaw \& Collinson, 1979; Wardlaw \& Collinson, 1986). However, biostratigraphic studies have not been carried out in Sheep Creek Valley. The presumed Guadalupian Age for the formation (based on outcrops $300 \mathrm{~km}$ to the west) has led previous geologists to assume a 4 to 7 -million-year hiatus at the top of the formation during the Lopingian Age, the last age of the Permian (Sprinkel et al. 2000). Study of the biostratigraphic age of the Park City Formation (particularly the upper Meade Peak Member) in Sheep Creek Valley is ongoing. The age of the Dinwoody Formation is widely regarded as earliest Triassic, Greisbachian Age (earliest Induan Age; Newell \& Kummel, 1942; Paull \& Paull, 1994, Hofmann et al. 2011). 


\section{Methods}

Located at $40^{\circ} 55^{\prime} 15.016^{\prime \prime}$ latitude, $109^{\circ} 40^{\prime} 22.026^{\prime \prime}$ longitude, the new Permian-Triassic section encompasses a thickness of 9 meters that brackets the lithologic boundary between the Meade Peak Member of the Park City Formation and lower Dinwoody Formation (Fig. 2). High resolution geochemical sampling every $5 \mathrm{~cm}$ was carried out from $50 \mathrm{~cm}$ below up to $200 \mathrm{~cm}$ above the lithologic contact. Additional samples were collected with a spacing of $50 \mathrm{~cm}$ from above and below this high resolution sampled zone, within the 9-meter section (Fig. 2). The stratigraphic section can be divided into five distinct zones based on color and lithology. The lowest zone (samples P-450 to P-5) represents a yellowish gray (Munsell 5Y 8/1) limestone (pelmicrite/pellet wackestone), representing the upper facies (Meade Peak Member) of the Permian Park City Formation. At the top of this zone, within $5 \mathrm{~cm}$ just below the lithologic contact (sample P-0), the limestone contains small crystals of hematite, which shifts the color to a grayish orange pink (Munsell 5YR 7/2). This upper contact layer has an undulating surface, but lacks any evidence of karstification or dissolution due to contact with meteoric water. This $5 \mathrm{~cm}$ layer was found to contain abundant Fe and Mn oxides through ICP-MS analysis, likely diagenetic in formation from trapped groundwater flow, as this layer abuts an overlaying aquiclude of impermeable mudstone. Above this contact layer is a $50 \mathrm{~cm}$ thick grayish orange (Munsell 10YR 7/4) massive mudstone (samples TR-0 to TR-45). Lacking sedimentary structures, the mudstone is poorly cemented, and represents the lowest contact layer of the Dinwoody Formation. Starting at $50 \mathrm{~cm}$ above the lithologic contact (samples TR-50 and TR-55) is a $10 \mathrm{~cm}$ yellowish brown (Munsell 10TR 6/2) siltstone. The final upper zone of the 
stratigraphic section (samples TR-60 to TR-450) is a yellowish gray (Munsell 5Y 8/1) shale,

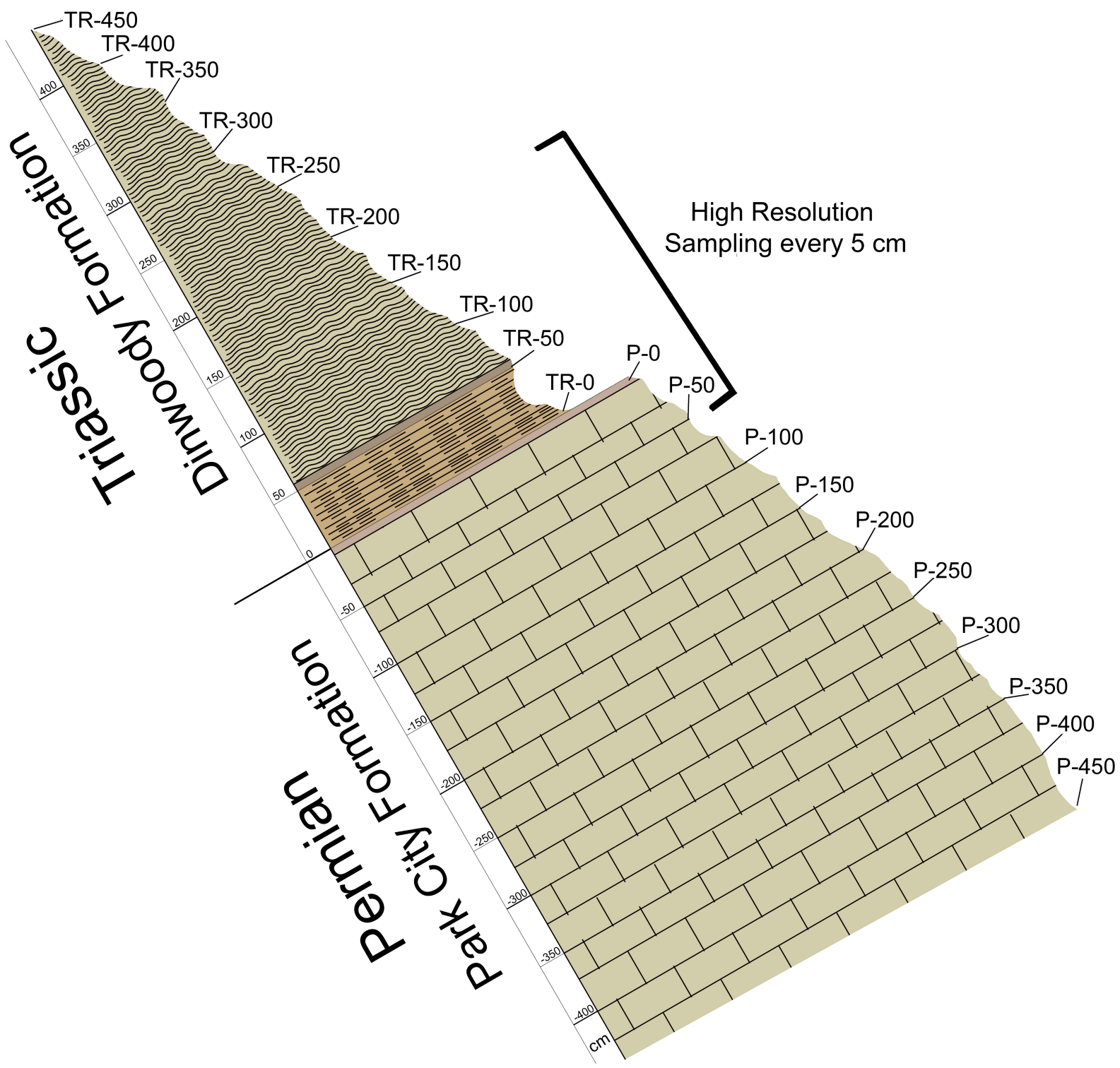

Fig. 2. Stratigraphic column of the entire 9 meter measured stratigraphic section across the lithologic contact between the Permian Park City and Triassic Dinwoody Formation, showing high resolution interval where sampling was conducted every $5 \mathrm{~cm}$. Beds are shown at their current $30^{\circ}$ dip. 
which features bi-directional cross laminae sedimentary structures (typical of tidal depositional environments), iron oxide concretions, and the cyclic appearance of small ( $\sim 5 \mathrm{~mm})$ pyrite framboid nodules. Gypsum, either as selenite crystals or druse is found in this upper zone.

\subsection{Carbonate Analysis}

Collected rock samples were crushed and ground to a fine powder in a pestle and mortar, and analyzed utilizing the methodology of Müller \& Gastner (1971), which measures pressure of carbon dioxide produced by reaction of carbonate with hydrochloric acid (37\%). Samples were calibrated with 2.00 grams of pure $\mathrm{CaCO}_{3}$ producing $90 \mathrm{kPa}$. Rock samples produced between a high of $75 \mathrm{kPa}$ with sample P-15, and a low of $15 \mathrm{kPa}$ with sample TR-105. Resampling resulted in differences of $\sim 3 \mathrm{kPa}$. Total percent by weight of carbonate in rock samples was calculated from these pressure readings, as well as mass balance using residue of selected samples.

\subsection{Total Organic Carbon, Sulfur, and Nitrogen Analysis}

Analysis of powdered rock samples utilized a ThermoFisher Scientific Flash 2000 Element Analyzer (EA) at the Uintah Basin Campus of Utah State University in Vernal, Utah. $20 \mathrm{mg}$ of each prepared powdered rock sample was placed in tin capsules with vanadium oxide. Prepared tin capsules were analyzed by the EA, which combusts samples at high temperature with a flow of oxygen and utilizes a carrier gas of helium. Reruns from the same source of powdered rock produced errors of $9.55 \%$ in nitrogen, and $0.25 \%$ in organic carbon, while rerun of standards produced errors of less than $0.01 \%$.

\subsection{Carbon Isotopic Analysis of Carbonate}

Carbon isotopes in the carbonate rock samples were analyzed using a ThermoFisher Scientific Delta V Advantage Isotope Ratio Mass Spectrometer (IRMS) with a Gasbench II Interface housed at the Utah State University Geology Department in Logan, Utah. Powdered rock 
samples and standards were measured into glass test tubes, with rock samples measured near 0.150 micrograms. Each prepared test tube was evacuated of atmospheric air with helium in an auto-sampler and injected with $1 \mathrm{~mL}$ (20 drops) of 100\% phosphoric acid. Four samples did not produce consistent enough peaks to be included (TR-180, P-0, P-15 and P-20). Replicates from the same rock source produced precision better than $\pm 0.43 \%$ in $\delta^{13} \mathrm{C}$ and $\pm 0.920 \%$ in $\delta^{18} \mathrm{O}$. All isotope data are reported as per mil (\%) relative to Vienna Pee Dee belemnite (VPDB) standard.

\subsection{ICP-MS Analysis}

The Inductively Coupled Plasma Mass Spectrometry (ICP-MS) at the Utah State University Geology Lab in Logan, Utah was used to determine elemental analysis of the 55 powdered rock samples. Measured 0.1000 grams of powdered rock was added to plastic vials and flushed with de-ionized water, nitric acid $\left(\mathrm{HNO}_{3}\right)$ and hydrofluoric acid $(\mathrm{HF})$ for digestion and heated to evaporation. Each concentrate was then prepared in a solution to determine concentrations of $\mathrm{Ti}$, V, Cr, Mn, Fe, Co, Ni, Cu, Zn, Ga, Rb, Sr, Pd, Ba, La, Ce, Eu, Pt, Pb, and U relative to lab standards. Concentrations of $\mathrm{Pd}$ and $\mathrm{Pt}$ are semi-quantifiable since those two standards were not used. All other values are fully-quantitative. Measurement error is reported as standard deviation and percent relative to the standard. Each sample was analyzed at least 5 times and averaged. Samples P-5, P-0, TR-0, and TR-5 were analyzed 10 times and averaged.

\subsection{Mercury Analysis}

Powdered samples were mailed to the University of Nevada in Reno in small plastic boxes. To prevent cross contamination on arrival each sample container was carefully cleaned individually using deionized water and Kim-wipes and transferred to a $7.5 \mathrm{ml}$ vial using a metal spatula cleaned with isopropyl. After this cleaning procedure, the vials with samples were placed in Ziploc bags for temporary storage. Each sample was then analyzed using a Milestone DMA 80. 
This instrument is used for EPA Method 7473 for $\mathrm{Hg}$ in solids and solutions by thermal decomposition, amalgamation, and atomic absorption spectrophotometry. The NIST 2702 inorganic sediment standard was used to set a calibration curve for the Milestone to measure 0$200 \mathrm{ng}$ of $\mathrm{Hg}$. This standard was used at the beginning of each run to verify the machine was on the set calibration curve. This calibration curve was checked with NIST1575a, 2976 and 2709. The average concentration of $\mathrm{Hg}$ for all 55 samples was 0.0054 parts per million (ppm). The lowest concentration of $\mathrm{Hg}$ was $0.00081 \mathrm{ppm}$, found in sample TR-190. The highest concentration of $\mathrm{Hg}$ was $0.02324 \mathrm{ppm}$, found in sample TR-5. The coefficient of variance for the triplicate samples $(n=5)$ was $14 \%$. The mean blank concentration for empty sample boats $(\mathrm{n}=15)$ was $0.00003 \mathrm{ppm}$. The minimum blank reading was $0.00001 \mathrm{ppm}$ and the maximum was 0.00007 ppm. The NIST 2702 standard had a mean recovery of $99.18 \%$, with a recovery range of $79.72 \%$ to $107.68 \%$.

\section{Results}

Results are summarized in the following section. The complete dataset of the geochemical analysis of rock samples can be found in the Supplementary Materials. $\mathrm{CaCO}_{3}$ content of the rock by weight abruptly drops across the lithologic contact (between samples P-0 and TR-0) from a range of $78-94 \%$ to a low of $50-72 \%$ by weight (Fig. 3; table S1). This drop in $\mathrm{CaCO}_{3}$ content is consistent with an abrupt shoaling of the CCD due to acidification of the ocean by the absorption of high levels of atmospheric $\mathrm{CO}_{2}$ (Zachos et al. 2005). 


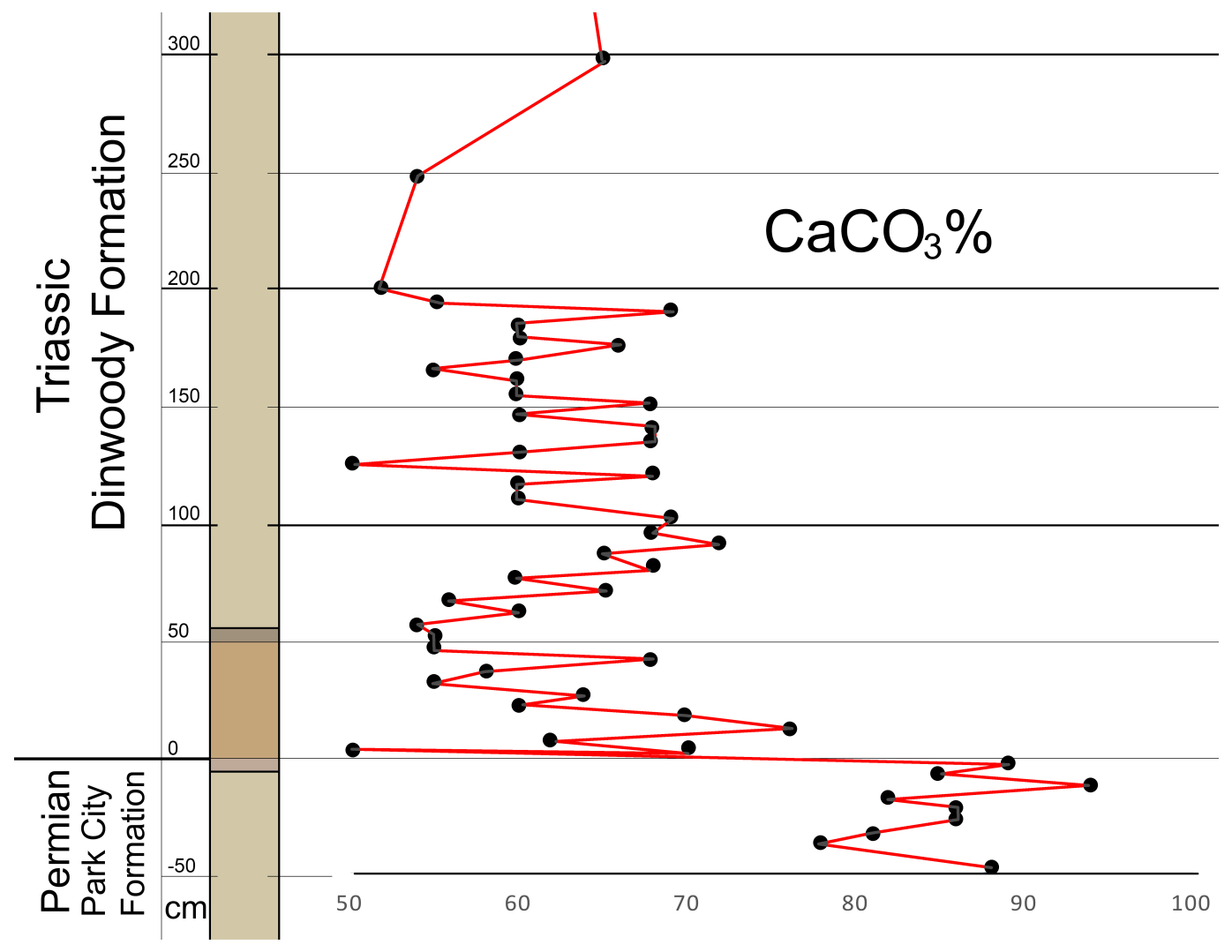

Fig. 3. Percent by weight of $\mathrm{CaCO}_{3}$ in collected rock samples (table $\mathrm{S} 1$ ).

Total Organic Carbon (TOC) content of the rocks shows an abrupt shift from an average of $14.83 \%$ to an average of $3.45 \%$ by weight across the lithologic contact (Fig. 4, table S2). This abrupt drop in TOC is interpreted as a significant loss of bioproductivity across this interval, and together with observed sedimentary structures it suggests that sea level remained within the photic zone and upper shoreface throughout the stratigraphic section. The major lithologic shift at the contact between samples P-0 and TR-0 is most-likely due to the effects of the extinction event, with decreased input of both $\mathrm{CaCO}_{3}$ and $\mathrm{TOC}$ in the lower-most Dinwoody Formation. 


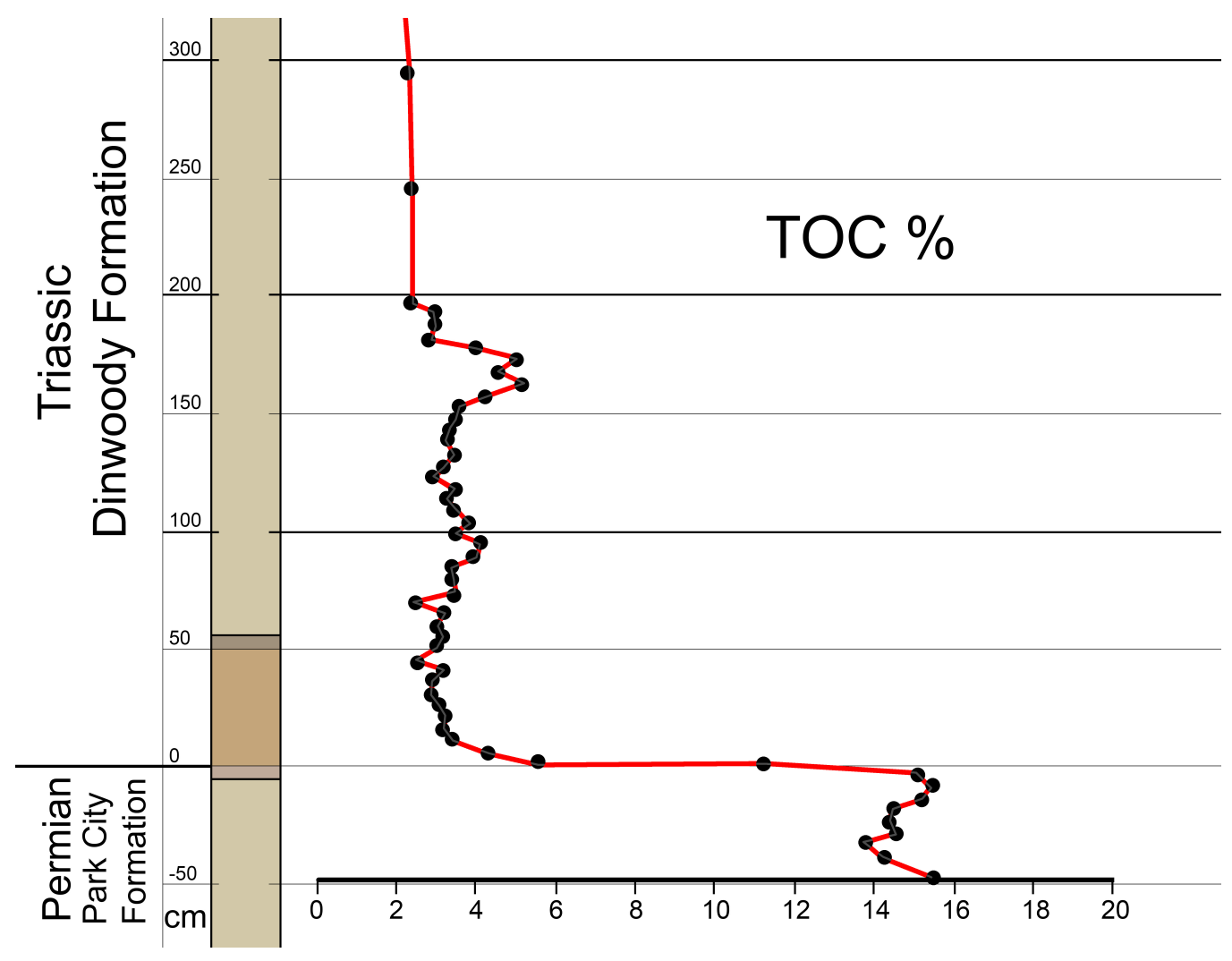

Fig. 4. Percent by weight of Total Organic Carbon (TOC) in collected rock samples (table S2).

Analysis of the sulfur content (S \%) of the rock layers shows a cyclic appearance of high levels of sulfur likely driven by the presence of pyrite framboids beginning with sample TR-70, $70 \mathrm{~cm}$ above the lithologic contact (Fig. 5, table S2). Presence of pyrite framboids has been documented from other Permian-Triassic sections (Wignall \& Hallam, 1992; Wignall et al. 2005; Kakuwa, 2008; Shen et al. 2007; Bond \& Wignall, 2010; Tian et al. 2014; Liao et al. 2017) and is indicative of widespread anoxic ocean waters following the Permian-Triassic event (Isozaki, 1997; Grice et al. 2005; Song et al. 2012). The presence of pyrite within the bi-directional cross laminae strata of the upper zone indicates that a severe anoxia of the upper shoreface followed the initial extinction event in Utah. Pyrite framboids appear to have been deposited cyclically, alternating between oxygenated and deoxygenated waters, with the highest concentration of 
sulfur in sample TR-195 $195 \mathrm{~cm}$ above the contact. Pyrite framboids are found widely distributed in these thinly bedded laminated shales and are non-sorted.

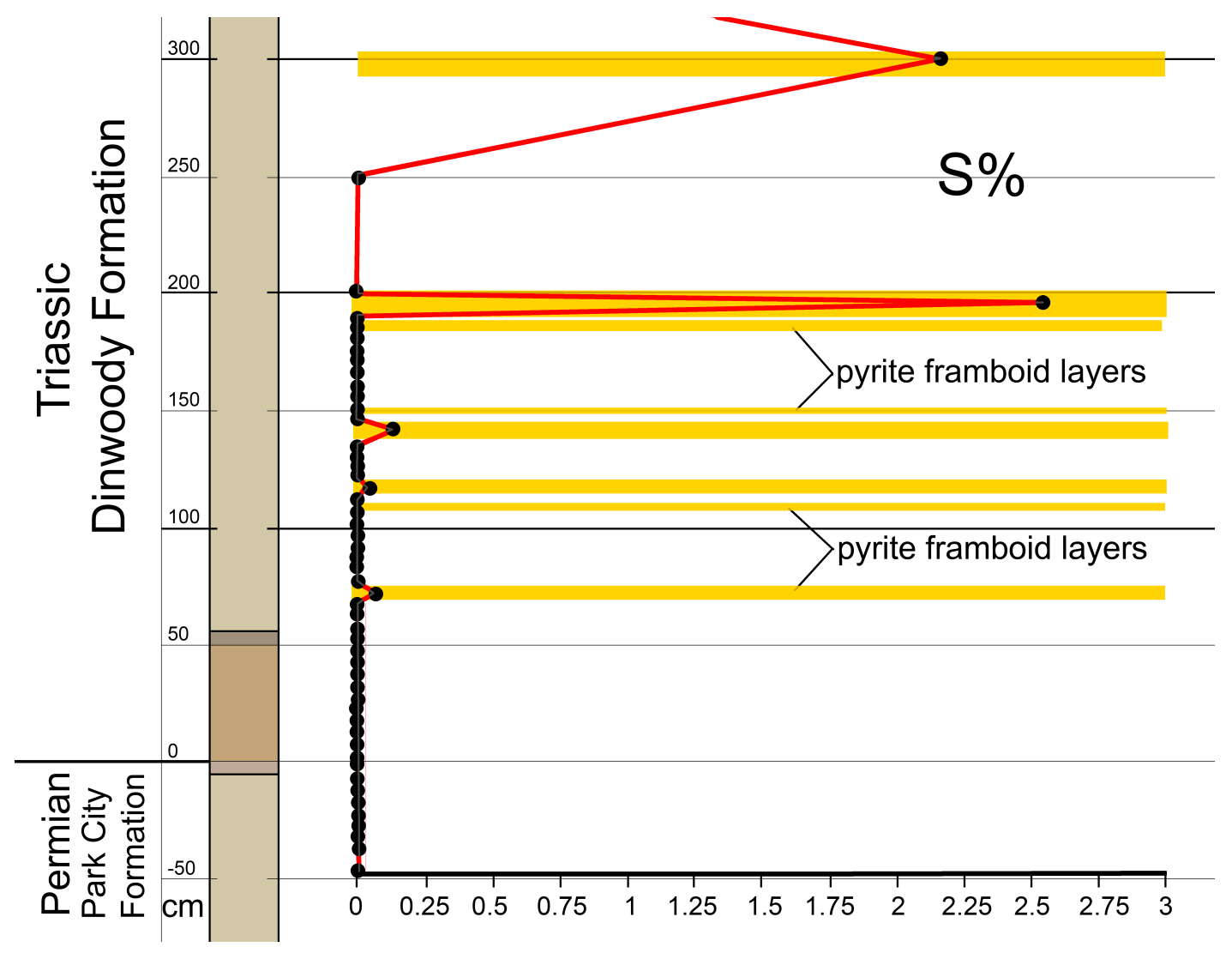

Fig. 5. Percent by weight of sulfur (S) in collected rock samples. Yellow lines indicate observed pyrite framboids in hand samples (table S1 and S2).

This pyrite may have formed at depth and been redeposited (Kershaw et al. 2018), but the presence of pyrite (even as clasts) indicates low dissolved oxygen content in these shallow marine waters. Pyrite framboids are common in the lower Dinwoody Formation, but are not found within the lower-most mudstone (TR-0 to TR-45). These samples (TR-0 to TR-45) contain low levels of sulfur, indicating a delay between the onset of ocean acidification and the onset of anoxia of $70 \mathrm{~cm}$ in the local section (Fig. 5). 
Carbon isotopic analysis $\left(\delta^{13} \mathrm{C}\right)$ of carbonate shows an overall decline in $\Delta^{13} \mathrm{C} /{ }^{12} \mathrm{C}$ ratios from a high of $2.585 \%$ VPDB $30 \mathrm{~cm}$ below the lithologic contact to a low of $-3.627 \%$ VPDB at $190 \mathrm{~cm}$ above the contact, similar to changes observed elsewhere at the Permian-Triassic boundary in shallow marine settings (Magaritz et al. 1988; Baud et al. 1989; Berner, 2002; Benton \& Twitchett, 2003; Payne et al. 2004; Korte et al. 2004; Krull et al. 2004; Sun et al. 2007; Korte \& Kozur, 2010; Luo et al. 2010; Meyer et al. 2011; Song et al. 2013; Meyer et al. 2013; Liu et al. 2017) (Fig. 7, table S3). In comparison to the GSSP section in Meishan, China, the observed gradual decrease in carbonate $\delta^{13} \mathrm{C}$ values in Utah closely matches that observed between beds 24 to 28 in China (Xie et al. 2007; Lui et al. 2010) during the greatest extinction of foraminifera (Song et al. 2009) and is remarkably similar to shallow marine environments along the south China craton (Sun et al. 2012; Song et al. 2013). The rate of carbon isotopic decrease is about $0.15 \%$ per $5 \mathrm{~cm}$, indicating a gradual negative shift in carbon isotopic ratios $\left(\delta^{13} \mathrm{C}\right)$ over $200 \mathrm{~cm}$ in the lower Dinwoody Formation. $\delta^{13} \mathrm{C}$ values remain low (sample TR-450 $=-2.034 \%$ VPDB) up to the top of the measured 9-m section in the lower Dinwoody Formation (Fig. 6). 


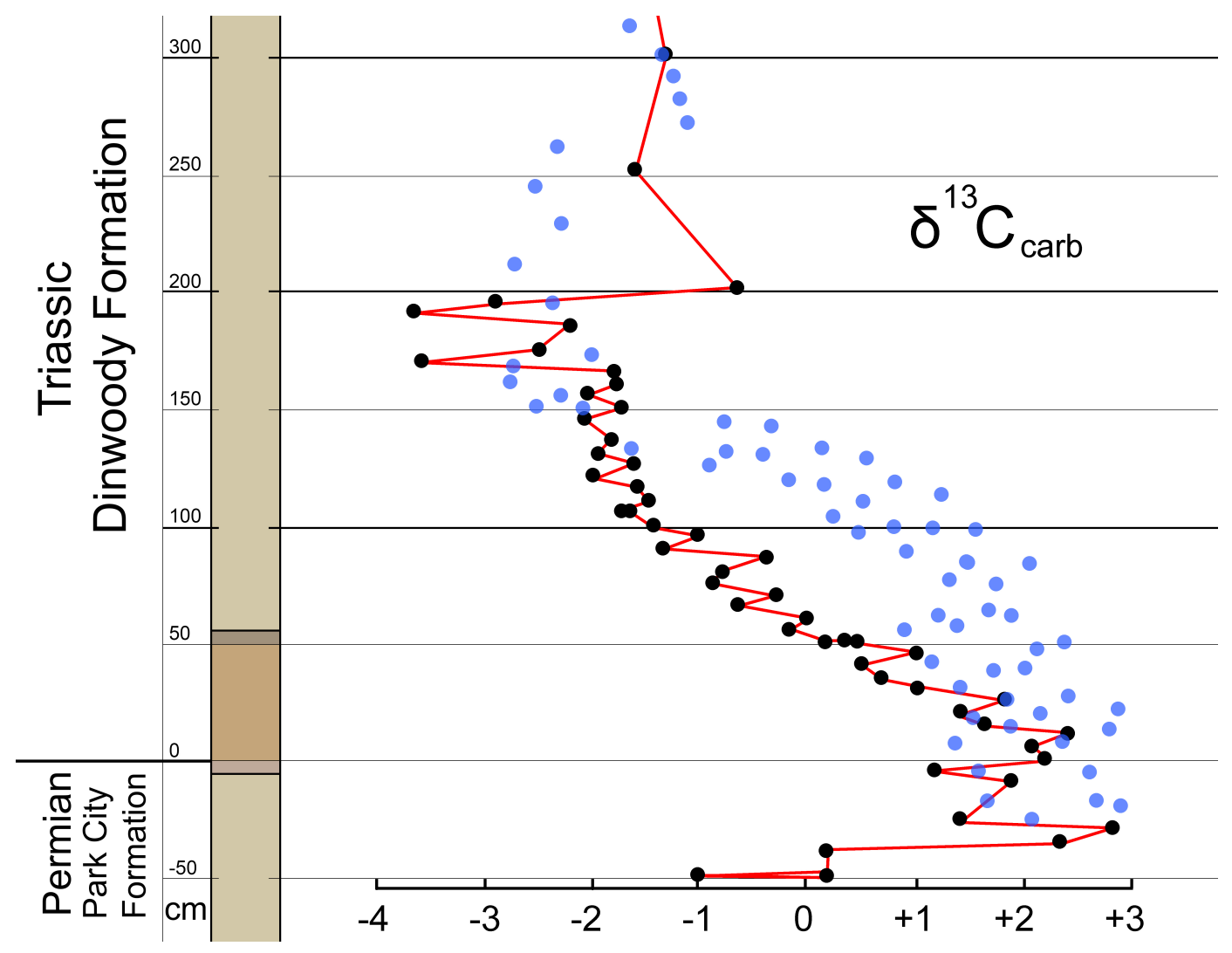

Fig. 6. Carbon isotope ratios of carbonate in collected rock samples. Values are in VPDB (\%o). Light blue dots are the observed $\delta^{13} \mathrm{C}$ values reported from the GSSP in Meishan China from beds 24 to 28 (Luo et al. 2010) (table S3).

Results from the nitrogen $(\mathrm{N})$ and copper $(\mathrm{Cu})$ analysis offer a mechanism to temporally calibrate the stratigraphic section (Fig. 7, table S2 and S6). Samples collected in the Park City Limestone show erratic $\mathrm{N}$ content, likely due to the heterogeneous nature of porous limestone, but $\mathrm{N}$ content from the mudstone/shale samples TR-0 to TR-200 show three rhythmic cycles of increasing and decreasing nitrogen values indicative of precession cycles ( $23 \mathrm{ky}$, Hays et al. 1976; Straub et al. 2013) in Earth's Milankovitch orbital variation. A similar cyclic pattern is observed in $\mathrm{Cu}$ obtained from ICP-MS analysis of rock samples (Fig. 6). Computer simulations of the Permian-Triassic ocean system show strong influence of precession orbital cycles on 
nutrient cycles, which would include temperature-dependent $\mathrm{N}$ levels and $\mathrm{Cu}$ input from variability in river discharge (Winguth \& Winguth, 2013).

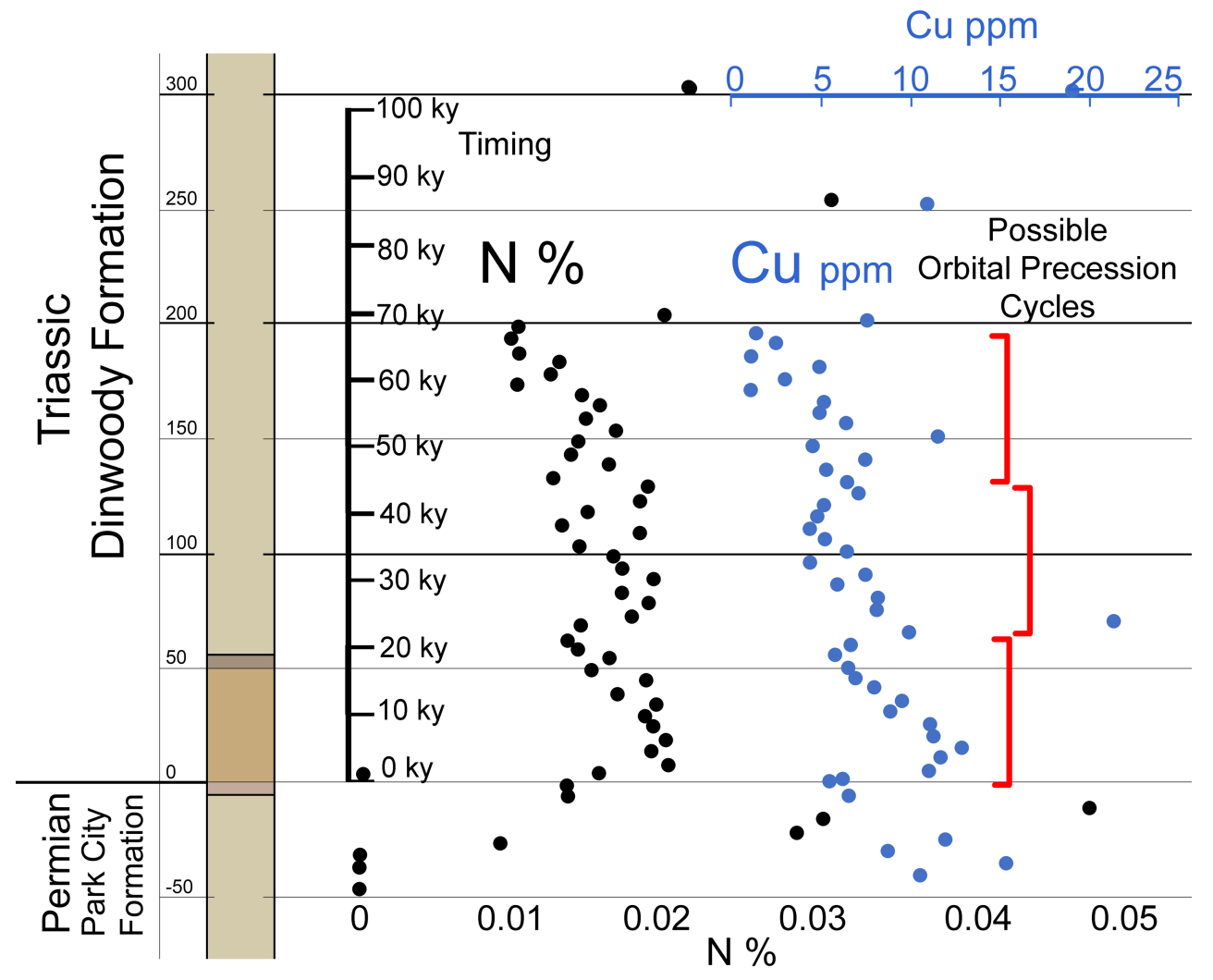

Fig. 7. Percent by weight of nitrogen $(\mathrm{N})$ and parts per million $(\mathrm{ppm})$ of copper $(\mathrm{Cu})$ in collected rock samples. Cyclic variation in $\mathrm{N} \%$ and $\mathrm{Cu}(\mathrm{ppm})$ in the early Dinwoody Formation shows three possible orbital precession cycles in the section, suggesting a temporal scale of $\sim 69,000$ years between TR-0 and TR-200 (table S2 and S6).

As interpreted the duration of the Permian-Triassic extinction (from 0 to $200 \mathrm{~cm}$ above the contact) occurred over $\sim 69,000$ years, which is consistent with U-Pb radiometric dates of zircon crystals from the GSSP section in Meishan, China (Shen et al. 2011; Burgess et al. 2014) between bed 25: $251.941 \pm 0.037 \mathrm{Ma}$ and bed 28: $251.880 \pm 0.031 \mathrm{Ma}$ or $\sim 61,000$ years, or between 13,000 to 109,000 years based on another study of that section (Baresel et al. 2017). The 
duration between the onset of shallow ocean acidification and ocean anoxia is estimated at $\sim 23,000$ years (samples TR-0 to TR-70), with a sedimentation rate of just $0.030 \mathrm{~mm} / \mathrm{year}$. These estimates are similar to durations calculated from orbital cyclicity observed in well cores across the Permian-Triassic boundary from the Austrian Alps ( $\sim 30,000$ to $\sim 40,000$ years) (Rampino et al. 2000). Based on sedimentation rates ( 0.5 to $2.0 \mathrm{~mm} /$ year) from a modern equivalent depositional environment (a protected bay in the Baltic Sea (Szmytkiewicz \& Zalewska, 2014)), a shorter duration of 1,400 to 350 years between ocean acidification and ocean anoxia is found. However, these shorter durations do not factor in the highly-reduced sedimentation rates expected in more acidic and less biologically active early Triassic oceans, where carbonate deposition was greatly reduced.

Analysis of the 55 rock samples for $\mathrm{Hg}$ content demonstrates a $\mathrm{Hg}$ enriched zone within the first $70 \mathrm{~cm}$ above the lithologic contact (Fig. 8, table S4). Two spikes in $\mathrm{Hg}$ were found at 5 $\mathrm{cm}(0.02324 \mathrm{ppm})$ and $70 \mathrm{~cm}(0.01966 \mathrm{ppm})$ above the contact, with background levels below $0.01 \mathrm{ppm}$. The results indicate a 2 to 4 -fold increase in $\mathrm{Hg}$ across the boundary. The high $\mathrm{Hg}$ content suggests a fallout of atmospheric ash from coal combustion (Grasby et al. 2011; Sanei et al. 2012; Grasby et al. 2016), coinciding with the lithologic shift due to the acidification of ocean water, and with the onset of euxinic ocean water that occurs at $70 \mathrm{~cm}$ above the lithologic contact with the first appearance of pyrite framboids. Sanei et al. (2012) hypothesize that Hg drawdown after the P-T event was a result of sulfide-Hg interactions from the onset of euxinic ocean water conditions. Indeed, these results from Utah support that assertion, as Hg levels decrease only after the first appearance of pyrite framboids in the local stratigraphic section (Fig. 8). 


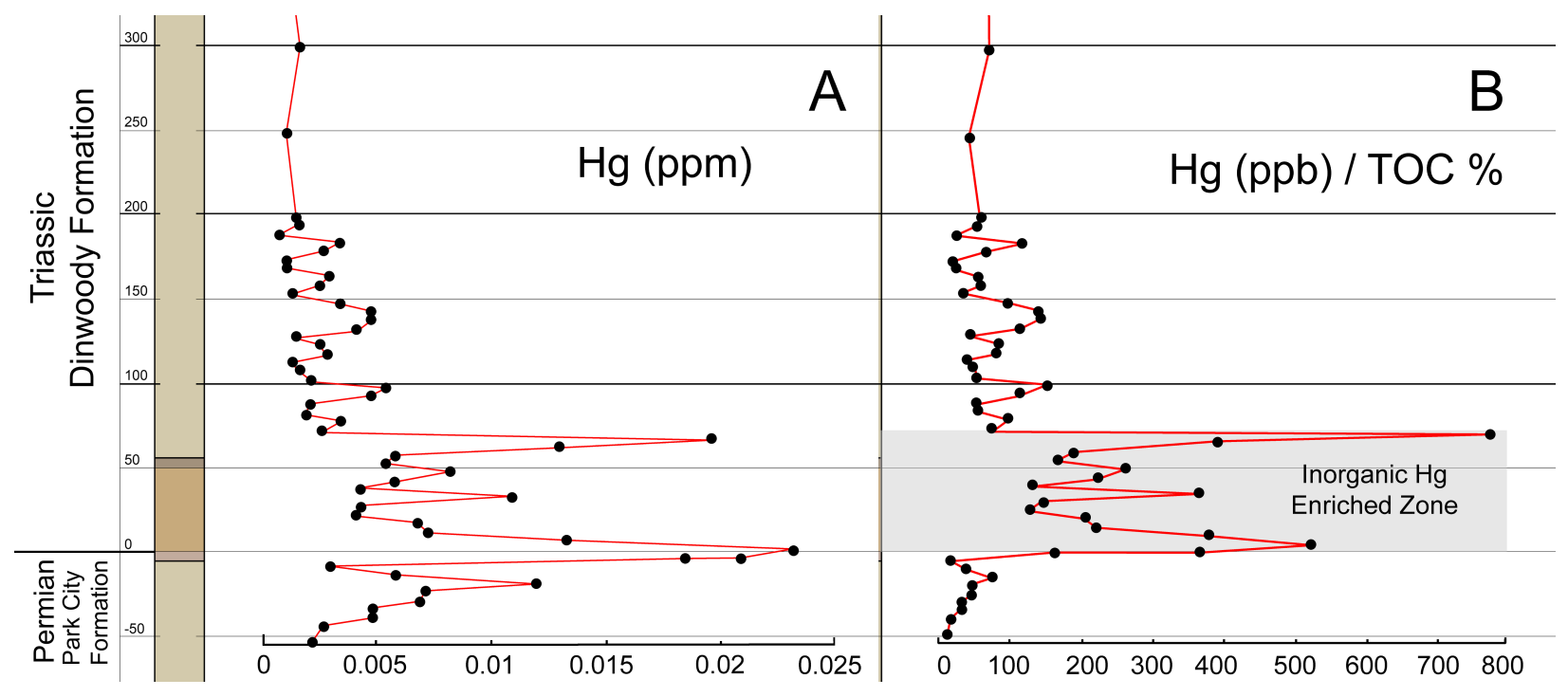

Fig. 8. Measured Hg concentrations in collected rock samples. (A) Hg concentrations in parts per million (ppm), and (B) ratio of $\mathrm{Hg}$ compared to measured TOC \% showing an enriched inorganic zone from TR-0 to TR-70 (table S4).

Analysis of the 55 rock samples utilizing an ICP-MS demonstrates only slightly elevated $\mathrm{Ni}$ content within the first $70 \mathrm{~cm}$ above the lithologic contact (Fig.9, table S5). Combined ${ }^{60} \mathrm{Ni}$ and ${ }^{62} \mathrm{Ni}$ peak at $65.2 \mathrm{ppm}$ at $70 \mathrm{~cm}$ and $61.0 \mathrm{ppm}$ at $25 \mathrm{~cm}$ above the contact, well below high levels ( $250 \mathrm{ppm}$ ) reported by Rampino et al. (2017), but near the $80 \mathrm{ppm}$ reported by Kaiho et al. (2001) within the Meishan Section in China. While Ni appears to be enriched within the boundary zone, the amount is not significant enough to implicate a volcanic source (Rampino et al. 2017). Nickel content in terrestrial soils becomes more mobile when exposed to lower $\mathrm{pH}$ water (Iyaka, 2011), and this slight enrichment of Ni may be from terrestrial runoff due to more acidic rainwater during the event (Sheldon, 2006). 


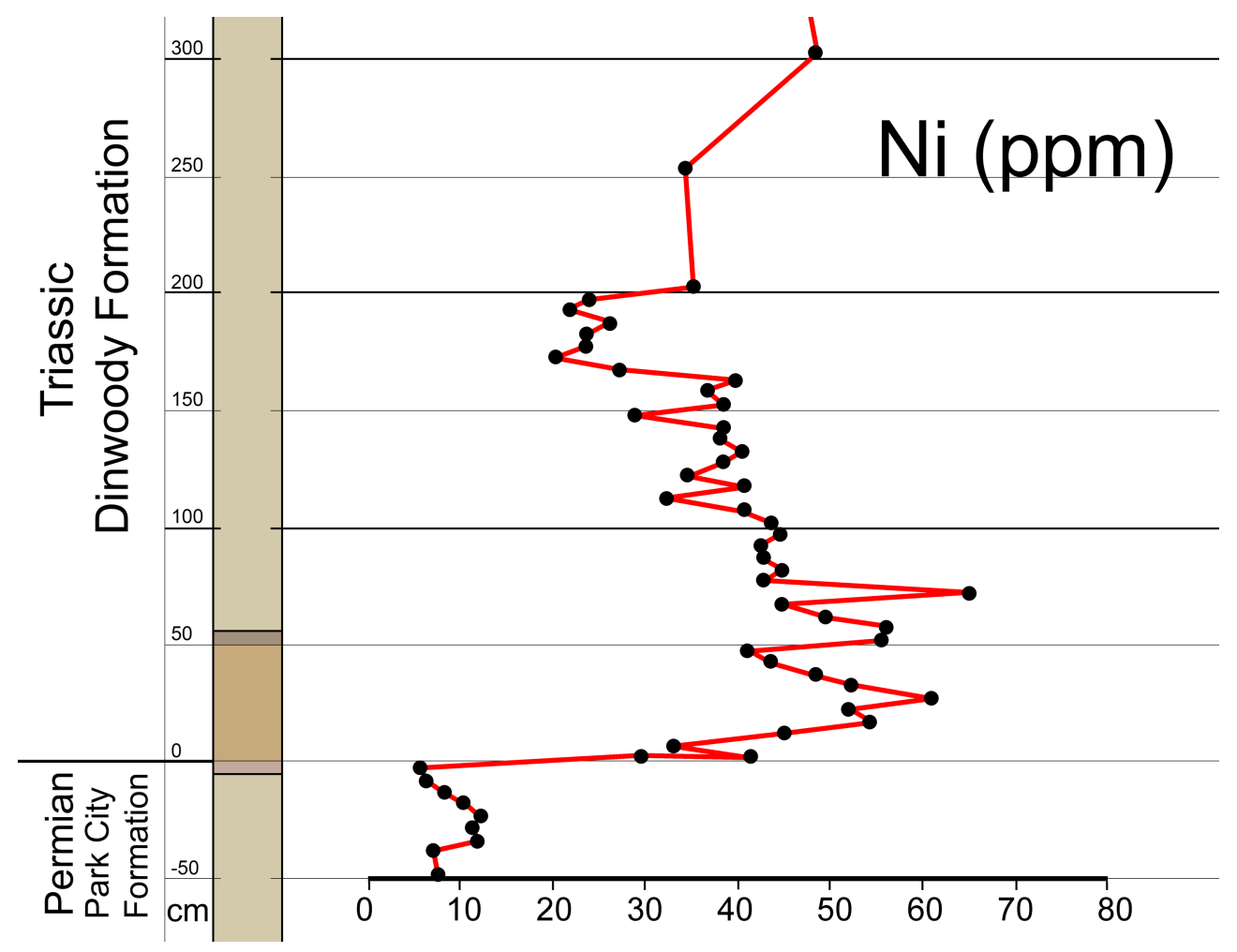

Fig. 9. Measured Ni concentrations (ppm) in collected rock samples, combined ${ }^{60} \mathrm{Ni}$ and ${ }^{62} \mathrm{Ni}$ isotopes from ICP-MS analysis. Concentrations are elevated in the Dinwoody Formation due to enhanced chemical weathering from terrigenous sources, but values are well below high-levels (greater than 200 ppm; Rampino et al. 2017) expected in volcanic ash or extraterrestrial impact events (table S5).

Zn on the other hand (Fig. 10, table S6), shows a more significant spike within the boundary interval, similar to results found by Liu et al. (2017) within the Meishan Section in China. In Utah, Zn peaks at $25 \mathrm{~cm}$ above the lithologic boundary to $87.4 \mathrm{ppm}$, while Liu et al. (2017) report Zn peaking just above 100 ppm in bed 24 of the Meishan Section, which, based on comparison of carbon isotopes, is correlative. 


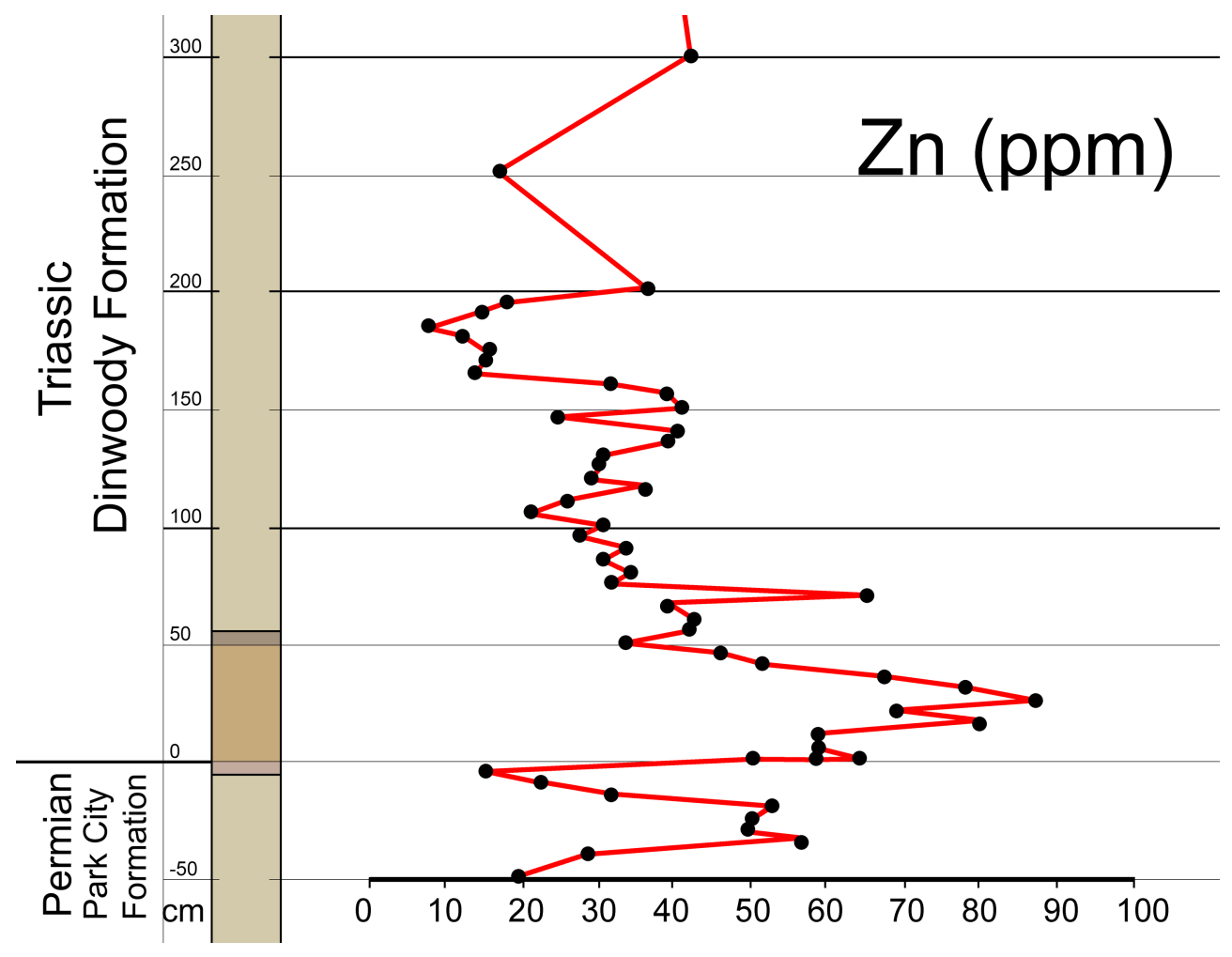

Fig. 10. Measured $\mathrm{Zn}$ concentrations (ppm) in collected rock samples from ICP-MS analysis.

Values peak within the boundary section at sample TR-25 at $87.4 \mathrm{ppm}$. Values are well below high-levels (greater than $300 \mathrm{ppm}$ ) expected with an extraterrestrial impact event (table S6).

Strontium (Sr) levels show a 3-fold increase in samples TR-0 and TR-5 from a background average of $213.1 \mathrm{ppm}$ to a peak of $617.2 \mathrm{ppm}$ just above the contact (Fig. 11, table $\mathrm{S} 7)$. Lead $(\mathrm{Pb})$ shows an elevated zone with values up to $14 \mathrm{ppm}$ near the contact (Samples TR-5 to TR-15), but also some additional spikes above $10 \mathrm{ppm}$ coinciding with pyrite-rich horizons, at TR-150 and TR-70 (Fig. 12). 


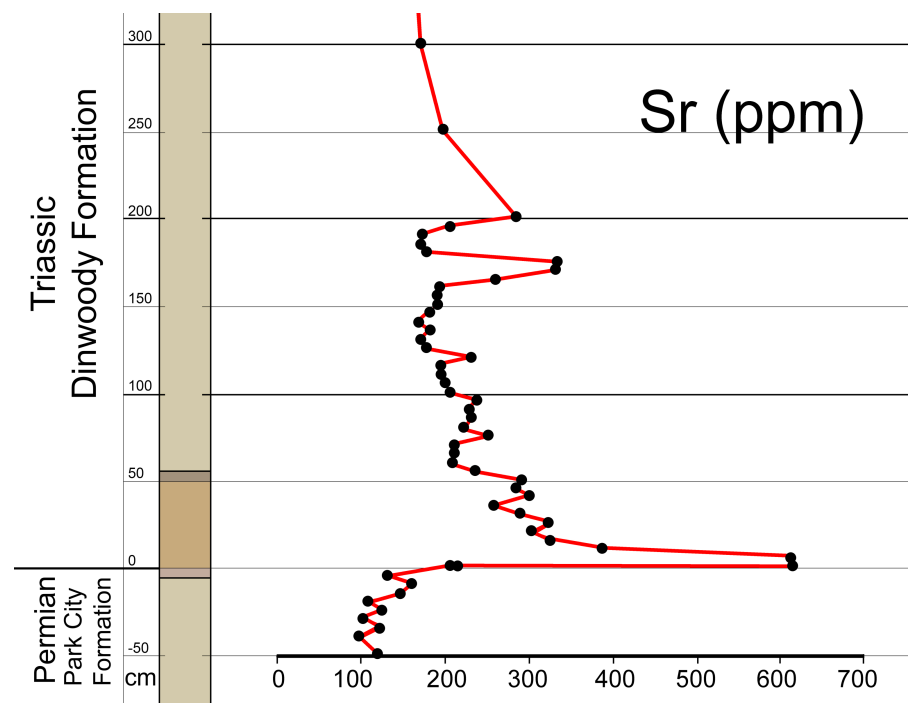

Fig. 11. Measured strontium ( $\mathrm{Sr}$ ) concentrations (ppm) in collected rock samples from ICP-MS analysis. Values peak at the base of the boundary section with sample TR- $0=617.5 \mathrm{ppm}$ and TR-5 = $615.1 \mathrm{ppm}($ table S7).

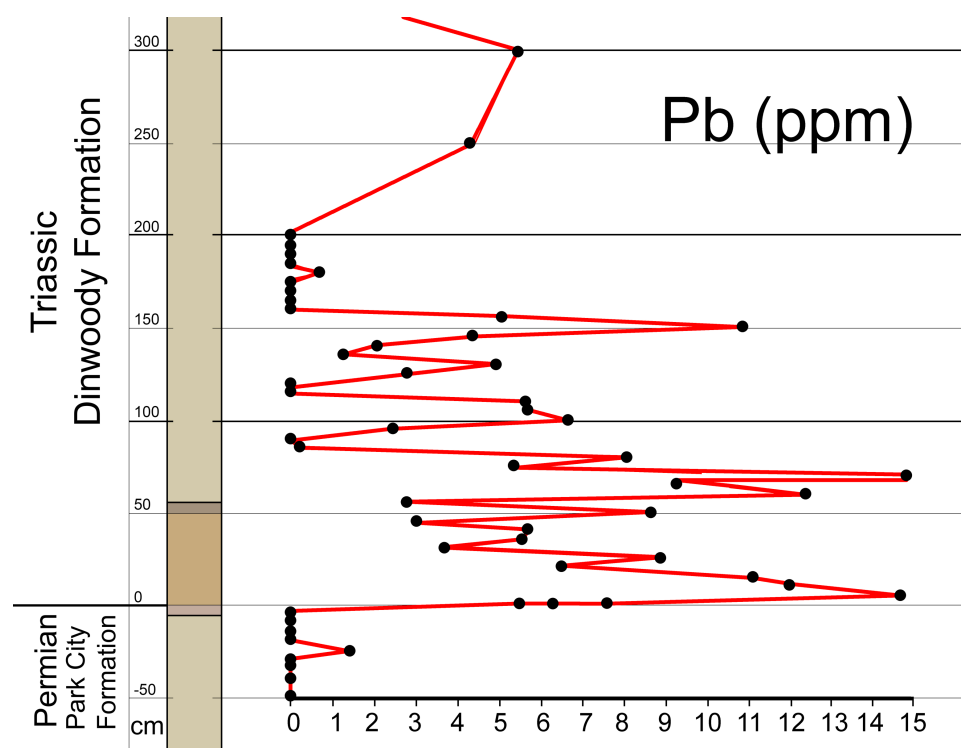

Fig. 12. Measured lead $(\mathrm{Pb})$ concentrations $(\mathrm{ppm})$ in collected rock samples from ICP-MS analysis. $\mathrm{Pb}$ is elevated in the lower Dinwoody Formation, especially within the lower boundary section (table S6). 
Lithology appears to have an effect on most trace elements observed in the stratigraphic column, due to a reduction in sedimentation rates. Mudstone/siltstone layers are enriched in $\mathrm{Ti}$, $\mathrm{V}, \mathrm{Fe}, \mathrm{Co}, \mathrm{Ni}, \mathrm{Ga}, \mathrm{Rb}, \mathrm{Ba}, \mathrm{La}, \mathrm{Ce}, \mathrm{Eu}$, and $\mathrm{Pb}$, while limestone layers are enriched in $\mathrm{Cu} . \mathrm{Cu}, \mathrm{Fe}$, $\mathrm{Ba}$ and $\mathrm{Mn}$ are slightly depleted in the zone between TR-0 to TR-70, with a slight enrichment in $\mathrm{Ti}, \mathrm{V}, \mathrm{Cr}, \mathrm{Co}, \mathrm{Ga}$, and $\mathrm{Rb}$ in this boundary zone, when compared to other mudstone/siltstone samples (tables S5-S7).

Observed amounts of barium (Ba) between TR- 0 and TR-70 show an increase up to 450 ppm (Fig. 13, table S7). However, in the anoxic upper zone (TR-70 to TR-195), Ba spikes several times, with the highest values (997.2 ppm) found in sample TR-170 (Fig. 13). These high-Ba spikes closely match the sulfur-enriched pyrite framboid horizons (Fig.13).

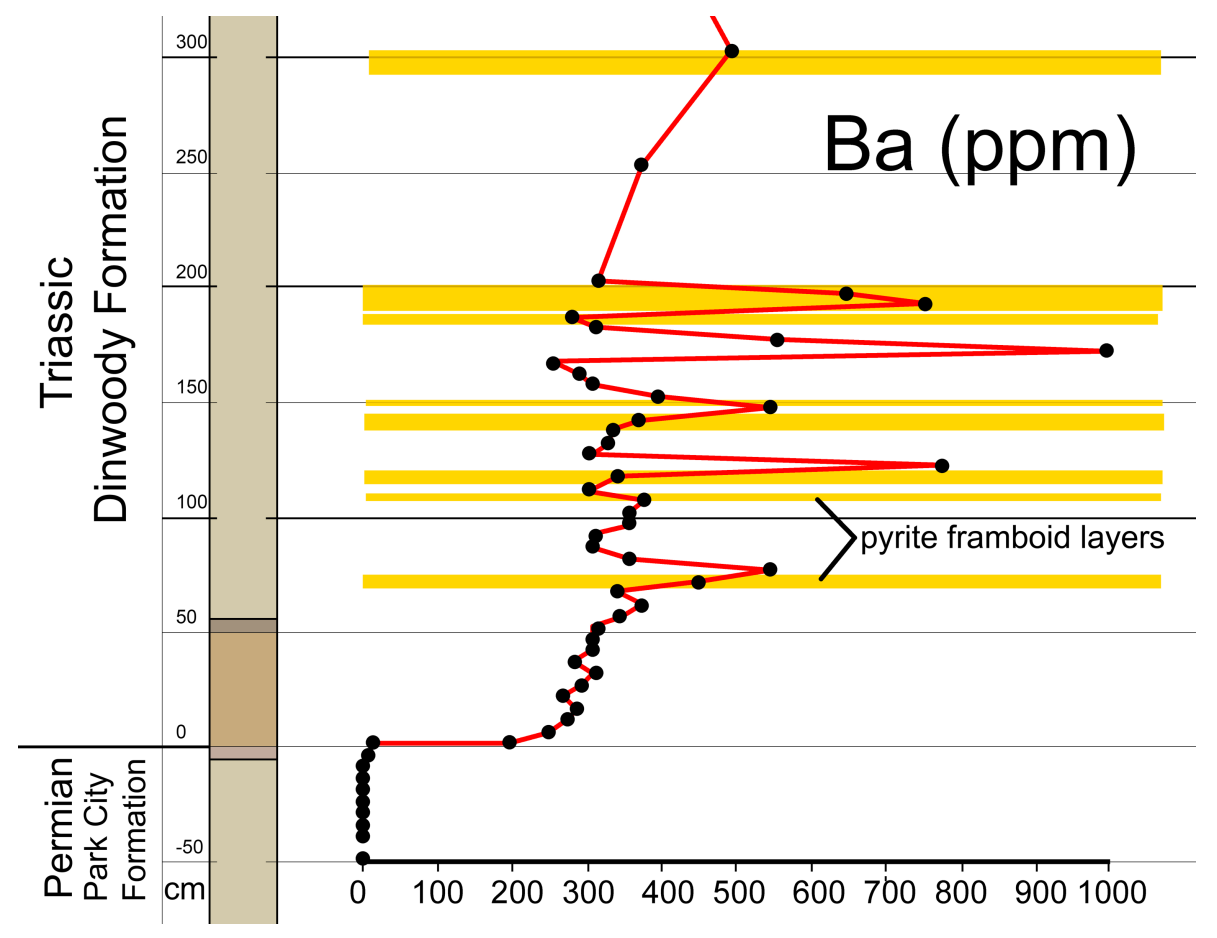

Fig. 13. Measured barium (Ba) concentrations ( $\mathrm{ppm}$ ) in collected rock samples from ICP-MS analysis. Ba is elevated in the observed pyrite framboid layers (table S7). 
Rare elements $\mathrm{La}, \mathrm{Ce}, \mathrm{Eu}, \mathrm{Pd}, \mathrm{Pt}$, and $\mathrm{U}$ show little difference stratigraphically across the boundary. Anomalous high values of siderophile and chalcophile elements $(\mathrm{Pt}, \mathrm{Pd}, \mathrm{Cr}, \mathrm{Co}, \mathrm{Ni}$, and $\mathrm{Zn}$ ) are indicative of extraterrestrial impact events, such as the one discovered at the end of the Mesozoic (Alvarez et al. 1980). Measured levels of these elements observed in the rock layers examined at the Permian-Triassic boundary in Utah remain well below anomalous high values reported from the Cretaceous-Paleogene boundary (Alvarez et al. 1980; Kyte et al. 1985) (Fig. 14, tables S5-S7). There is no evidence in the observed concentrations of siderophile and chalcophile elements in Utah for an extraterrestrial impact at the Permian-Triassic boundary (Fig. 14).

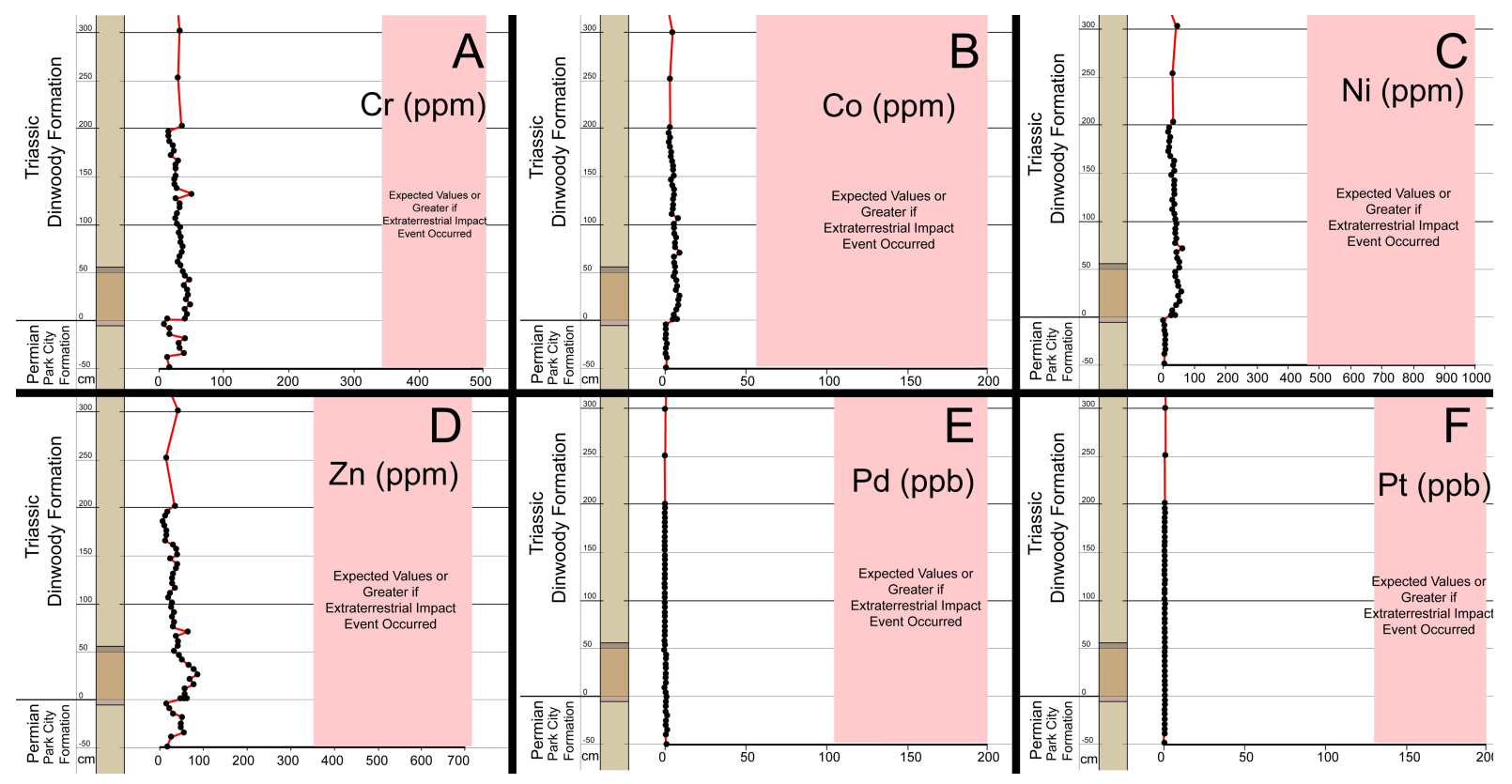

Fig. 14. Measured concentrations of elements (A) Chromium, (B) Cobalt, (C) Nickel, (D) Zinc, (E) Palladium, (F) and Platinum in collected rock samples from ICP-MS analysis compared with concentrations observed across the Mesozoic-Cenozoic boundary sections (pink zone) (Alvarez et al. 1980; Kyte et al. 1985). All measured concentrations are well below those found during extraterrestrial impact events. 


\section{Discussion}

This study is the first to examine the Permian-Triassic boundary from a shallow marine setting along the western coastline of Pangea. Previous studies of sediments deposited in shallow marine environments during the Permian-Triassic extinction have principally come from Asia, particularly within deposits representing the Paleo-Tethys Ocean and far eastern coastline of the Panthalassa Ocean (Wignall \& Twitchett, 2002). Assessing similarities and differences between the newly discovered section in Utah, and those in Asia, offers a unique view into the changing chemistry of the Panthalassa Ocean as a whole, which covered as much as $75 \%$ of the Earth's surface during this time. Measured values of siderophile and chalcophile element concentrations in Utah demonstrate a lack of evidence for an extraterrestrial impact event at the PermianTriassic boundary, which is consistent with observations at other boundary sections (Xu et al. 2007; Brookfield et al. 2010).

Recent research has focused on the Siberian Traps large volcanic providence as the trigger for the Permian-Triassic event, due in large part to the well constrained dates from the basalt fields, which tie these eruptions temporally within the boundary interval (Renne \& Basu, 1991; Renne et al. 1995; Mudil et al. 2004; Payne et al. 2004; Reichow et al. 2009; Burgess et al. 2014; Burgess et al. 2017; Latyshev et al. 2018). Estimates of the total amount of carbon dioxide emitted from these large volcanic providences (440 to 13,000 gigatonnes of $\mathrm{CO}_{2}$; Leavitt, 1982; Berner, 2002), was likely alone not enough to push the entire Panthalassa Ocean into the acidic conditions necessary to lead to the observed reduction in shallow marine carbonate deposition in the stratigraphic sections of both Asia and Utah. Volcanic basalts from the Siberian Traps eruptions, however, overlay coal-bearing sedimentary rocks (Reichow et al. 2009). Burgess et al. 
(2017) have advanced the idea that the Siberian Traps volcanic providence spread into a regional sill complex, which ignited coal deposits during a second stage of volcanic activity starting at 251.9 million years ago. Recently, evidence from the Tunguska Basin north of Irkutsk, Russia demonstrates a vast network of sill intrusions into hydrocarbon rich sedimentary rocks, enough to release an estimated 100,000 gigatonnes of $\mathrm{CO}_{2}$ (Svensen et al. 2009). Such a scenario would have significantly increased the total carbon dioxide output, enough to acidify the Panthalassa Ocean, then volcanic activity alone. The combustion of large quantities of coal releases significantly larger amounts of carbon dioxide, but also sulfur, $\mathrm{Hg}, \mathrm{Zn}, \mathrm{Pb}$, and $\mathrm{Sr}$, which differ geochemically from volcanic ash.

Atmospheric Hg bio-accumulates in plant tissues (Gustin et al. 2008), which become sequestered in the formation of coal. When coal is combusted this $\mathrm{Hg}$ is released back into the atmosphere, where it can be observed as fallout in soils and sediments. The observed enriched zone of $\mathrm{Hg}(0-70 \mathrm{~cm})$ within the Permian-Triassic boundary section in Utah supports the idea of coal combustion as the initial driver of the Permian-Triassic extinction, rather than volcanic activity alone. Elevated levels of $\mathrm{Zn}$ (above $60 \mathrm{ppm}$ ) were also found in the basal $70 \mathrm{~cm}$ of the boundary section, which further supports the influence of coal emissions during this time. Coal ash contains higher levels of Zn (55 to 1,300 ppm; Doughten, 1997; Briggs, 1997) due to the element's role as a micronutrient in plant tissue, when compared to low $\mathrm{Zn}$ levels in volcanic ash (0 to 92 ppm; Taylor \& Lichte, 1980; Smichowski et al. 2003). Reported values of $\delta^{66} \mathrm{Zn}$ from the Permian-Triassic boundary in China ( $+0.35 \%$; Liu et al. 2017$)$ are within the range of observed coal ash $\delta^{66} \mathrm{Zn}(+0.26 \%$ to $+0.64 \%$; Ochoa-González et al. 2015). The basal $5 \mathrm{~cm}$ of the boundary section in Utah also show an anomalous doubling of $\mathrm{Sr}$ (up to $617.2 \mathrm{ppm}$ ). Sr is typically found at higher levels in coal (190 to 2,100 ppm; Doughten, 1997; Briggs, 1997) 
compared to volcanic ash (345 to 567 ppm; Taylor \& Lichte, 1980). Observed elevated levels of $\mathrm{Sr}$ in this basal $5 \mathrm{~cm}$ zone may also be due to an increased input from terrestrial sources due to increased chemical weathering, as paleosols across the Permian-Triassic boundary in South Africa show a depletion in Sr levels (Sheldon, 2006), resulting in elevated input in marine sediments from this enhanced weathering. Emissions from burning coal contribute to higher levels of $\mathrm{Pb}$ in the atmosphere (Natusch et al. 1974; Block \& Dams, 1975). Measured amounts of $\mathrm{Pb}$ in the Utah section show an enriched $\mathrm{Pb}$-layer between samples TR-0 to TR-155, suggesting continued coal emission throughout this time and coinciding with the observed negative carbon isotope excursion.

The elevated levels of $\mathrm{Hg}, \mathrm{Zn}, \mathrm{Sr}$, and $\mathrm{Pb}$ within the $70 \mathrm{~cm}$ basal zone of the PermianTriassic boundary in Utah support coal combustion as the trigger for the initial change in $\mathrm{pH}$ chemistry within the Panthalassa Ocean, rather than volcanic activity alone. The lack of any observed volcanic ash in the Utah section contrasts with sections in Asia which record a number of volcanic ash layers near the Permian-Triassic boundary (Lehrmann et al. 2003; Rampino et al. 2017), attributed to eruptions of the nearby Siberian Traps volcanic providence. While these eruptions were major events, the distribution of volcanic ash from these eruptions was not global, as it appears that volcanic ash did not reach the far western coastline of Pangea, represented by present-day Utah.

Combustion of subterranean petroleum reservoirs associated with Siberian Traps volcanism could also account for the high levels of $\mathrm{Hg}$, especially if these reservoirs were enriched in the mineral calomel. Heating experiments of Cambrian petroleum-bearing evaporitic rocks associated with contact metamorphism by the Siberian Traps sill complex also exhibit elevated chloride, fluoride, and bromide (Svensen et al. 2009; Black et al. 2012), which were not 
examined in this study. Beerling et al. (2007) theorized high input of atmospheric chloride (as $\mathrm{CH}_{3} \mathrm{Cl}$ ) was necessary to deplete the ozone layer enough to explain observed malformed pollen and spores documented during the event (Hochuli et al. 2010; Hochuli et al. 2017). Further study of the chemical signature of coal-bearing rocks associated with the Siberian Traps sill complex may help trace the various sources of hydrocarbons in the region responsible for the event. Such a large input of carbon dioxide from combustion of coal and associated hydrocarbons into the atmosphere could be expected to have led to significant global warming, desertification, and an atmosphere rich in carbon dioxide (Sun et al. 2012).

The observed negative shift in carbon isotope ratios $\left(\delta^{13} \mathrm{C}\right)$ matches the expected increase in ${ }^{12} \mathrm{C}$ in the atmosphere from the combustion of ${ }^{12} \mathrm{C}$-enriched coal reserves over an estimated 69 kyr duration (Shen et al. 2011). In Utah, the $\delta^{13} \mathrm{C}$ values continue to decrease beyond the initial lithologic boundary layer, suggesting continued input of ${ }^{12} \mathrm{C}$-enriched carbon from organic sources beyond both the initial acidification event and widespread anoxia that followed. This latter part of the $\delta^{13} \mathrm{C}$ excursion could also be attributed to the consequences of global warming produced by the coal emissions, such as methane hydrate upwelling, and an overall decrease in photosynthesizing organisms. Together, these subsequent events likely enriched the sedimentary carbonate further in ${ }^{12} \mathrm{C}$ (Wignall, 2007).

As theorized, a scenario of a rapidly warming ocean (Song et al. 2014), which quickly became acidic, resulted in the dissolution of carbonate-rich shelled organisms (Garbelli et al. 2016). These acidic ocean waters also caused the death of many oxygen-producing photosynthesizing calcareous algae, which accumulated as dead organic matter on the ocean's floor (Wang et al. 1994; Hall-Spencer et al. 2008; Chen et al. 2011). This massive input of organic matter into the ocean floor was consumed by oxic bacteria, which used available 
dissolved oxygen, converting it to carbon dioxide. Oxygen-levels were further decreased in the ocean as ocean temperatures rose, since warmer ocean water holds less dissolved oxygen (Sun et al. 2012).

An initial massive combustion of coal would have enriched the atmosphere in $\mathrm{SO}_{2}$, which interacts with water vapor and nitric oxide to form toxic sulfuric acid that could have killed terrestrial plants and animals (Wang et al. 2016). Large amounts of sulfur would have entered the anoxic marine waters as sulfate ions $\left(\mathrm{SO}_{4}{ }^{2-}\right)$. Lacking available oxygen, these sulfate ions would have been utilized by sulfate-reducing bacteria, which require high levels of organic content in the sediment and anoxic conditions (Berner, 1984). However, TOC\% values across the PermianTriassic boundary remain relatively low during the deposition of the pyrite framboid horizons (Fig. 4), indicating that the sulfate-reducing bacteria utilized a different source of hydrocarbons than organic matter in the form of dead or decaying biomass, as discussed below.

Elevated Ba spikes are observed in the Utah Permian-Triassic boundary section coinciding with sulfur-enriched pyrite framboid horizons (Fig. 13). Enriched Ba-levels have been observed in shallow marine sediment cores across the Paleocene-Eocene Thermal Maximum event (Dickens et al. 2003), where high Ba-levels have been interpreted as indicative of the sudden release of seafloor gas hydrates (Dickens et al. 2003). High-Ba zones in shallow marine sediments are indicative of the release of these seafloor gas hydrates due to the interaction of $\mathrm{Ba}^{+}$ with sulfate. $\mathrm{Ba}^{+}$enters ocean water from deep seafloor hydrothermal vents. In normal oxygenrich ocean conditions, high concentrations of $\mathrm{SO}_{4}{ }^{2-}$ are typically confined to the ocean floor as it is produced by bioturbation by benthic organisms and oxidation of microbial $\mathrm{H}_{2} \mathrm{~S}$ (Canfield \& Farquhar, 2009). At depth, $\mathrm{SO}_{4}^{2-}$ reacts with $\mathrm{Ba}^{+}$forming precipitates of solid barite crystals $\left(\mathrm{BaSO}_{4}\right)$, which accumulate in deep ocean floor sediments (Torres et al. 1996). Over time, deep 
ocean floor environments are enriched in $\mathrm{Ba}$, but also methane molecules which are locked in a solid form within a lattice of water molecules called clathrates. As deep ocean water temperatures rise, these clathrates can sublimate into a gas, releasing large quantities of methane $\left(\mathrm{CH}_{4}\right)$ and $\mathrm{Ba}$ from the ocean floor. When there is a major out-gassing of methane hydrate, Balevels will increase in shallow nearshore marine sediments (Torres et al. 1996). Sulfate-reducing bacteria utilized the enriched ocean water concentration of methane and sulfate near the ocean surface through microbially mediated anaerobic methane oxidation:

$$
\begin{gathered}
\mathrm{CH}_{4}+\mathrm{SO}_{4}{ }^{2-} \rightarrow \mathrm{HCO}_{3}{ }^{-}+\mathrm{HS}^{-}+\mathrm{H}_{2} \mathrm{O} \\
\mathrm{HS}^{-}+\mathrm{H}^{+} \rightarrow \mathrm{H}_{2} \mathrm{~S}
\end{gathered}
$$

The isotopic fractionation of sulfur isotopes resulting from these reactions explains the isotope excursions of $\delta^{34} \mathrm{~S}_{\mathrm{CAS}}$ observed from other Permian-Triassic sections (Shen et al. 2011; Kajiwara et al. 1994; Zhang et al. 2017; Algeo et al. 2008), which show anomalies above the PermianTriassic boundary associated with pyrite-rich (anoxic) zones. As a consequence, the oceans emitted large quantities of toxic $\mathrm{H}_{2} \mathrm{~S}$ gas, as well as methane, which likely entered the atmosphere during this second stage of the Permian-Triassic mass extinction event (Song et al. 2014). In Utah, within 23,000 years of acidic conditions, shallow marine waters were anoxic and enriched in enough dissolved $\mathrm{H}_{2} \mathrm{~S}$ gas (euxinic) to begin to precipitate pyrite framboids in near shore tidal anoxic environments (Rickard, 1997; Peiffer et al. 2015). Such a scenario may account for the two closely-spaced extinction levels documented in the shallow marine PermianTriassic section in China (Xie et al. 2005; Peiffer et al. 2015).

Coupled with the effects of global warming and acid rains, high levels of $\mathrm{H}_{2} \mathrm{~S}$ gas from the ocean has been theorized to have resulted in toxic atmospheric conditions for many terrestrial organisms (Krump et al. 2005; Meyer et al. 2008). In Utah, these anoxic nearshore ocean waters 
were cyclic or periodic. Quickly moving organisms, such as fish, may have been able to navigate away from these oxygen-depleted waters and were better adapted to find refuge than sessile and planktonic organisms with a fixed habitat range. This may explain the dramatic rise in fish diversity and other active swimming animals following the mass extinction event (Sun et al. 2012; Schaeffer, 1973; Dineen et al. 2014; Romano et al. 2016), with near-extinction of sessile organisms like crinoids, brachiopods, rugosa and tabulate corals, and organisms with planktonic larva (Raup, 1979; Valentine, 1986; Erwin, 1994; Benton \& Twitchett, 2003; Chen et al. 2010; Payne \& Clapham, 2012).

\section{Conclusions}

No evidence was found in the Utah section to suggest an extraterrestrial impact event or massive volcanism was responsible for the Permian-Triassic extinction; rather, the assembled geochemical evidence suggests a massive combustion of coal as the event responsible for Earth's largest mass extinction event. The combustion of large amounts of coal resulted in acidic ocean water, global warming, and the release of methane hydrates from the seafloor. Together these events led to a planet inhospitable to life. This study opens many avenues of inquiry, such as how much coal (and other associated hydrocarbons) was burned at the Permian-Triassic boundary during the Siberian Traps volcanism? How does this quantity compare to modern levels of hydrocarbon combustion? How close are we to a similar mass extinction happening again?

\section{Acknowledgements}

The author gratefully thanks M. S. Gustin and M. V. Estrada at the University of Nevada-Reno for running the $\mathrm{Hg}$ analysis, $\mathrm{S}$. Lyman for productive discussion of $\mathrm{Hg}$ detection and $\mathrm{E}$. Swanner 
for productive discussion of pyrite formation. A. Lonero and D. Newell for help running samples through the ICP-MS and Mass-Spec. at Utah State University in Logan, and L. Jolley, Z. JolleyBurger, and F. Jolley-Burger for help collecting samples in the field. Available data from analyses are listed in the Supplementary Materials. Personal funds were used to conducted the research.

\section{References}

Algeo, T., Shen, Y., Zhang, T., Lyons, T., Bates, S., Rowe, H., Nguyen, T.K.T., 2008. Association of ${ }^{34} \mathrm{~S}$-depleted pyrite layers with negative carbonate $\delta^{13} \mathrm{C}$ excursions at the Permian-Triassic boundary: evidence for upwelling of sulfidic deep-ocean water masses. Geochem. Geophys. Geosys. 9 Q04025 1-10. https://doi.org/10.1029/2007gc001823

Alvarez, L.W., Alvarez, W., Asaro, F., Michel, H.V., 1980. Extraterrestrial cause for the Cretaceous-Tertiary extinction. Science 208 1095-1108. https://doi.org/10.1126/science.208.4448.1095

Alvarez, W., O’Connor, D. 2002. 'Permian-Triassic boundary in the southwestern United States: hiatus or continuity?" in Catastrophic Events and Mass Extinctions: Impacts and Beyond C. Koeberl, K. G. MacLeod Eds. (GSA Special Paper), 356, pp. 385-393. https://doi.org/10.1130/0-8137-2356-6.385

Baresel, B., Bucher, H., Bagherpour, B., Brosse, M., Guodun, K., Schaltegger, U., 2017. Timing of global regression and microbial bloom linked with the Permian-Triassic boundary mass extinction: implications for driving mechanisms. Scientific Reports 743630 1-8. https://doi.org/10.1038/srep43630

Baud, A., Magaritz, M., Holser, W.T., 1989. Permian-Triassic of the Tethys: carbon isotope studies. Geol. Rundsch. 78/2 649-677. https://doi.org/10.1007/bf01776196

Beerling, D.J., Harfoot, M., Lomax, B., Pyle, J.A., 2007. The stability of the stratospheric ozone layer during the end-Permian eruption of the Siberian Traps. Phil. Trans. R. Soc. A 365 1843-1866. https://doi.org/10.1098/rsta.2007.2046

Benton, M.J., Twitchett, R.J., 2003. How to kill (almost) all life: the end-Permian extinction event. Trends Ecol. Evol. 18 358-365. https://doi.org/10.1016/s0169-5347(03)00093-4

Berner, R.A., 1984. Sedimentary pyrite formation: an update. Geochimica et Cosmochimica Acta 48 605-615. https://doi.org/10.1016/0016-7037(84)90089-9

Berner, R.A., 2002. Examination of hypotheses for the Permo-Triassic boundary extinction by carbon cycle modeling. Proc. Natl. Acad. Sci. U.S.A. $994172-4177$. https://doi.org/10.1073/pnas.032095199 
Berner, R.A. 2006. Carbon, sulfur, and $\mathrm{O}_{2}$ across the Permian-Triassic boundary. Journal of Geochem. Exploration 88 416-418. https://doi.org/10.1016/j.gexplo.2005.08.088

Black, B.A., Elkins-Tanton, L.T., Rowe, M.C., Peate, I.U., 2012. Magnitude and consequences of volatile release from Siberian Traps. Earth Planet Sci. Lett. 317-318 363-373. https://doi.org/10.1016/j.epsl.2011.12.001

Block, C., Dams, R., 1975. Lead contents of coal, coal ash and fly ash. Water, Air, and Soil Pollution. 5 207-211. https://doi.org/10.1007/bf00282962

Bond, D.P.G., Wignall, P.B., 2010. Pyrite framboid study of marine Permian-Triassic boundary sections: a complex anoxic event and its relationship to contemporaneous mass extinction. Geol. Soc. Am. Bull. 122 1265-1279. https://doi.org/10.1130/b30042.1

Brayard, A., Krumenacker, L. J., Botting, J. P., Jenks, J. F., Bylund, K. G., Fara, E., Vennin, E., Olivier, N., Goudemand, N., Saucède, T., Charbonnier, S., Romano, C., Doguzhaeva, L., Thuy, B., Hautmann, M., Stephen, D. A., Thomazo, C., Escarguel, G., 2017. Unexpected early Triassic marine ecosystem and the rise of the modern evolutionary fauna. Science Advances 3, e1602159. https://doi.org/10.1126/sciadv.1602159

Brennecka, G.A., Herrmann, A.D., Algeo, T.J., Anbar, A.D., 2011. Rapid expansion of oceanic anoxia immediately before the end-Permian mass extinction. Proc. Natl. Acad. Sci. U.S.A. 108 17631-17634. https://doi.org/10.1073/pnas.1106039108

Briggs, P.H., 1997. "Determination of 25 elements in coal ash from 8 Argonne premium coal samples by Inductively Coupled Argon Plasma-Atomic Emission Spectrometry" in The chemical analysis of Argonne premium coal samples, C. A. Palmer ed. U.S. Geol. Surv. Bull. 2144, pp. 39-44. https://pubs.usgs.gov/bul/2144/report.pdf

Brookfield, M.E., Shellnutt, J.G., Qi, L., Hannigan, R., Bhat, G.M., Wignall, P.B., 2010. Platinum element group variations at the Permo-Triassic boundary in Kashmir and British Columbia and their significance. Chem. Geol. 272 12-19. https://doi.org/10.1016/j.chemgeo.2010.01.008

Burgess, S.D., Bowring, S., Shen, S.-Z., 2014. High-precision timeline for Earth's most severe extinction. Proc. Natl. Acad. Sci. U.S.A. $1113316-3321$. https://doi.org/10.1073/pnas.1317692111

Burgess, S.D., Murihead, J.D., Bowring, S.A., 2017. Initial pulse of Siberian Traps sills as the trigger of the end-Permian mass extinction. Nature Comm. 8, 164 1-6. https://doi.org/10.1038/s41467-017-00083-9

Canfield, D.E., Farquhar, J., 2009. Animal evolution, bioturbation, and the sulfate concentration of the oceans. Proc. Natl. Acad. Sci. U.S.A. 106 8123-8127. https://doi.org/10.1073/pnas.0902037106 
Chen, J., Tong, J., Song, H., Luo, M., Huang, Y., Xiang, Y., 2015. Recovery pattern of brachiopods after the Permian-Triassic crisis in south China. Palaeogeogr. Paleoclimatol. Palaeoecol. 433 91-105. https://doi.org/10.1016/j.palaeo.2015.05.020

Chen, L., Wang, Y., Xie, S., Kershaw, S., Dong, M., Yang, H., Liu, H., Algeo, T.J., 2011. Molecular records of microbialites following the end-Permian mass extinction in Chongyang, Hubei Province, South China. Palaeogeogr. Palaeoclimatol. Palaeoecol. 308 151-159. https://doi.org/10.1016/j.palaeo.2010.09.010

Chen, Z.-Q., Tong, J., Liao, Z.-T., Chen, J., 2010. Structural changes of marine communities over the Permian-Triassic transition: ecologically assessing the end-Permian mass extinction and its aftermath. Global Planet. Change 73 123-140. https://doi.org/10.1016/j.gloplacha.2010.03.011

Dickens, G.R., Fewless, T., Thomas, E., Bralower, T.J., 2003. "Excess barite accumulations during the Paleocene-Eocene Thermal Maximum: massive input of dissolved barium from seafloor gas hydrate reservoirs" in Causes and Consequences of Globally Warm Climates in the early Paleogene, S. L. Wing, P. D. Gingerich, B. Schmitz, E. Thomas, Eds. (GSA Special Paper 2003), 369, pp. 11-23. https://doi.org/10.1130/0-8137-2369$\underline{8.11}$

Dineen, A.A., Fraiser, M.L., Sheehan, P.M., 2014. Quantifying functional diversity in pre- and post-extinction paleocommunities: a test of ecological restructuring after the end-Permian mass extinction. Earth-Sci. Rev. 136 339-349. https://doi.org/10.1016/j.earscirev.2014.06.002

Doughten, M.W., 1997. "Determination of select elements in coal ash from eight Argonne premium coal samples by atomic absorption spectrometry and atomic emission spectrometry" in The chemical analysis of Argonne premium coal samples, C. A. Palmer ed. U.S. Geol. Surv. Bull. 2144, pp. 33-37. https://pubs.usgs.gov/bul/2144/report.pdf

Erwin, D.H., 1994. The Permo-Triassic extinction. Nature 367 231-236. https://doi.org/10.1038/367231a0

Fraiser, M. L., Bottjer, D. J. 2007. Elevated atmospheric $\mathrm{CO}_{2}$ and the delayed biotic recovery from the end-Permian mass extinction. Palaeogeogr. Palaeoclimatol. Palaeoecol. 252 164-175. https://doi.org/10.1016/j.palaeo.2006.11.041

Garbelli, C., Angiolini, L., Shen, S.-Z. 2016. Biomineralization and global change: A new perspective for understanding the end-Permian extinction. Geology 45 19-22. https://doi.org/10.1130/g38430.1

Grasby, S.E., Beauchamp, B., Bond, D.P.G., Wignall, P.B. Sanei, H. 2016. Mercury anomalies associated with three extinction events (Capitanian Crisis, Latest Permian extinction and the Smithian/Spathian extinction) in NW Pangea. Geol. Mag. 153 285-297. https://doi.org/10.1017/s0016756815000436 
Grasby, S.E., Sanei, H., Beauchamp, B., 2011, Catastrophic dispersion of coal fly-ash into oceans during the latest Permian extinction. Nature Geoscience 4 104-107. https://doi.org/10.1038/ngeo1069

Grice, K., Cao, C., Love, G.D., Böttcher, M.E., Twitchett, R.J., Grosjean, E., Summons, R.E., Turgeon, S.C., Summons, R.E., Turgeon, S.C., Dunning, W., Jin, Y., 2005. Photic zone euxinia during the Permian-Triassic superanoxic event. Science 307 706-709. https://doi.org/10.1126/science.1104323

Gustin, M.S., Lindberg, S.E., Weisberg, P.J., 2008. An update on the natural sources and sinks of atmospheric mercury. Appl. Geochem. 23 482-493. https://doi.org/10.1016/j.apgeochem.2007.12.010

Hall-Spencer, J.M., Rodolfo-Metalpa, R., Martin, S., Ransome, E., Fine, M., Turner, S.M., Rowley, S.J., Tedesco, D., Buia, M.-C., 2008. Volcanic carbon dioxide vents show ecosystem effects of ocean acidification. Nature 454 96-99. https://doi.org/10.1038/nature07051

Hays, J.D., Imbrie, J., Shackleton, N.J., 1976. Variations in the Earth's Orbit: Pacemaker of the Ice Ages. Science 194 1121-1132. https://doi.org/10.1126/science.194.4270.1121

Hochuli, P.A., Hermann, E., Vigran, J.O., Bucher, H., Weissert, H., 2010. Rapid demise and recovery of plant ecosystems across the end-Permian extinction event. Global Planet. Change 74 144-155. https://doi.org/10.1016/j.gloplacha.2010.10.004

Hochuli, P.A., Schneebeli-Hermann, E., Mangerud, G., Bucher, H., 2017. Evidence for atmospheric pollution across the Permian-Triassic transition. Geology 45 1123-1126. https://doi.org/10.1130/g39496.1

Hofmann, R., Hautmann, M., Bucher, H., 2013. New paleoecological look at the Dinwoody Formation (Lower Triassic, Western USA): Intrinsic versus extrinsic controls on ecosystem recovery after the end-Permian mass extinction. J. Paleontol. 87 854-880. https://doi.org/10.1666/12-153

Hongfu, Y., Kexin, Z., Jinnan, T., Zunyi, Y., Shunbao, W., 2001. The global stratotype section and point (GSSP) of the Permian-Triassic boundary. Episodes 24 102-114. http://www.stratigraphy.org/bak/Induan.pdf

Isozaki, Y., 1997. Permo-Triassic boundary super anoxia and stratified super ocean: records from lost deep sea. Science 276 235-238. https://doi.org/10.1126/science.276.5310.235

Iyaka, Y.A., 2011. Nickel in soils: a review of its distribution and impacts. Sci. Res. Essays 6 6774-6777. https://doi.org/10.5897/srex11.035

Jin, Y.G., Wang, Y., Wang, W., Shang, Q.H., Cao, C.Q., Erwin, D.H. 2000. Pattern of marine mass extinction near the Permian-Triassic boundary in south China. Science 289432 436. https://doi.org/10.1126/science.289.5478.432 
Kaiho, K., Kajiwara, Y., Nakano, T., Miura, Y., Kawahata, H., Tazaki, K., Ueshima, M., Chen, Z., Shi, G.R., 2001. End-Permian catastrophe by a bolide impact: evidence of a gigantic release of sulfur from the mantle. Geology 29 815-818. https://doi.org/10.1130/00917613(2001)029<0815:epcbab $>2.0$. co;2

Kajiwara, Y., Yamakita, S., Ishida, K., Ishiga, H., Imai, A., 1994. Development of a largely anoxic stratified ocean and its temporary massive mixing at the Permian/Triassic boundary supported by the sulfur isotope record. Palaeogeogr. Palaeoclimatol. Palaeoecol. 111 367-379. https://doi.org/10.1016/0031-0182(94)90072-8

Kakuwa, Y., 1996. Permian-Triassic mass extinction event recorded in bedded chert sequence in southwestern Japan. Palaeogeogr. Palaeoclimatol. Palaeoecol.121 35-

51.https://doi.org/10.1016/0031-0182(95)00070-4

Kakuwa, Y., 2008. Evaluation of palaeo-oxygenation of the ocean bottom across the PermianTriassic boundary. Global Planet. Change 63 40-56. https://doi.org/10.1016/j.gloplacha.2008.05.002

Kershaw, S., Tang, H., Li, Y., Guo, L., 2018. Oxygenation in carbonate microbialites and associated facies after the end-Permian mass extinction: problems and potential solutions. J. Palaeogeo. 2018. https://doi.org/10.1016/j.jop.2017.10.001

Kershaw, S., Zhang, T., Lan, G., 1999. A ?microbialite carbonate crust at the Permian-Triassic boundary in South China, and its palaeoenvironmental significance. Palaeogeogr. Palaeoclimatol. Palaeoecol. 146 1-18. https://doi.org/10.1016/s0031-0182(98)00139-4

Korte, C., Kozur, H.W., 2010. Carbon-isotope stratigraphy across the Permian-Triassic boundary: a review. J. Asian Earth Sci. 39 215-235. https://doi.org/10.1016/j.jseaes.2010.01.005

Korte, C., Kozur, H.W., Joachimski, M.M., Strauss, H., Veizer, J., Schwark, L. 2004. Carbon, sulfur, oxygen and strontium isotope records, organic geochemistry and biostratigraphy across the Permian/Triassic boundary in Abadeh, Iran. Int. J. of Earth Sci. 93 565-581. https://doi.org/10.1007/s00531-004-0406-7

Krull, E.A., Lehrmann, D.J., Druke, D., Kessel, B., Yi, Y., Li, R. 2004. Stable carbon isotope stratigraphy across the Permian-Triassic boundary in shallow marine carbonate platforms, Nanpanjiang Basin, south China. Palaeogeogr. Palaeoclimatol. Palaeoecol. 204 297315. https://doi.org/10.1016/s0031-0182(03)00732-6

Krull, E.S., Retallack, G.J., Campbell, H.J., Lyon, G. L., 2000. $\delta^{13} C_{\text {org }}$ chemostratigraphy of the Permian-Triassic boundary in the Maitai Group, New Zealand: Evidence for highlatitudinal methane release. New Zealand J. of Geol. and Geophysics 43 21-32. https://doi.org/10.1080/00288306.2000.9514868

Kump, L., Pavlov, A., Arthur, M.A., 2005. Massive release of hydrogen sulfide to the surface ocean and atmosphere during intervals of oceanic anoxia. Geology 33 397-400. https://doi.org/10.1130/g21295.1 
Kyte, F.T., Smit, J., Wasson, J.T., 1985. Siderophile interelement variations in the CretaceousTertiary boundary sediments from Caravaca, Span. Earth Planet. Sci. Lett. 73 183-195. https://doi.org/10.1016/0012-821x(85)90067-6

Latyshev, A.V., Veselovshiy, R.V., Ivanov, A.V., 2018. Paleomagnetism of the Permian-Triassic intrusions from the Tunguska syncline and the Angara-Taseeva depression, Siberian Traps large igneous province: evidence of contrasting styles of magmatism. Tectonophysics 723 41-55. https://doi.org/10.1016/j.tecto.2017.11.035

Leavitt, S.W., 1982. Annual volcanic carbon dioxide emission: an estimate from eruption chronologies. Environ. Geology 4 15-21. https://doi.org/10.1007/bf02380495

Lehrmann, D.J., Payne, J.L., Felix, S.V., Dillett, P.M., 2003. Permian-Triassic boundary sections from shallow-marine carbonate platforms of the Nanpanjiang Basin, south China: implications for oceanic conditions associated with the end-Permian extinction and its aftermath. Palaios 18 138-152. https://doi.org/10.1669/08831351(2003)18<138:pbsfsc $>2.0 . \operatorname{co} ; 2$

Le Vaillant, M., Barnes, S.J., Mungall, J.E., Mungall, E.L., 2017. Role of degassing of the Noril'sk nickel deposits in the Permian-Triassic mass extinction event. Proc. Natl. Acad. Sci. U.S.A. 114 2485-2490. https://doi.org/10.1073/pnas.1611086114

Liao, W., Bond, D.P.G., Wang, Y., He, L., Yang, H., Weng, Z., Li, G., 2017. An extensive anoxic event in the Triassic of the South China block: a pyrite framboid study from Dajiang and its implications for the cause(s) of oxygen depletion. Palaeogeogr. Palaeoclimatol. Palaeoecol.486 86-95. https://doi.org/10.1016/j.palaeo.2016.11.012

Liu, S.-A., Wu, H., Shen, S.-Z., Jiang, G., Zhang, S., Lv, Y., Zhang, H., Li, S., 2017. Zinc isotope evidence for intensive magmatism immediately before the end-Permian mass extinction. Geology 45 343-346. https://doi.org/10.1130/g38644.1

Luo, G., Kump, L.R., Wang, Y., Tong, J., Arthur, M.A., Yang, H., Huang, J., Yin, H., Xie, S., 2010. Isotopic evidence for an anomalously low oceanic sulfate concentration following the end-Permian mass extinction. Earth Planet. Sci. Lett. 300 101-111. https://doi.org/10.1016/j.eps1.2010.09.041

Magaritz, M., Bär, R., Baud, A., Holser, W.T., 1988. The carbon-isotope shift at the Permian/Triassic boundary in the southern Alps is gradual. Nature 331 337-339. https://doi.org/10.1038/331337a0

Meyer, K.M., Kump, L.R., Ridgwell, A., 2008. Biogeochemical controls on photic-zone euxinia during the end-Permian mass extinction. Geology 36 747-750. https://doi.org/10.1130/g24618a.1 
Meyer, K.M., Yu, M., Jost, A.B., Kelly, B.M., Payne, J.L., 2011. $\delta^{13}$ C evidence that high primary productivity delayed recovery from end-Permian mass extinction. Earth Planet. Sci. Lett. 302 378-384. https://doi.org/10.1016/j.epsl.2010.12.033

Meyer, K.M., Yu, M., Lehrmann, D., Van de Schootbrugge, B., Payne, J.L., 2013. Constraints on early Triassic carbon cycle dynamics from paired organic and inorganic carbon isotope records. Earth Planet. Sci. Lett. 361 429-435. https://doi.org/10.1016/j.epsl.2012.10.035

Müller, G., Gastner, M., 1971. The "karbonat-bomb", a simple device for the determination of the carbonate content in sediments, soils and other materials. Neues Jahrb. Mineral. Abh. 10 466-469.

Mundil, R., Ludwig, K.R., Metcalfe, I., Renne, P.R., 2004. Age and timing of the Permian mass extinctions: U/Pb dating of closed-system zircons. Science 305 1760-1763. https://doi.org/10.1126/science.1101012

Natusch, D.F.S., Wallace, J.R., Evans C.A. Jr., 1974. Toxic trace elements: preferential concentrations in respirable particles. Science 183 202-204. https://doi.org/10.1126/science.183.4121.202

Newell, N.D. and Kummel, B., 1942. Lower Eo-Triassic stratigraphy, western Wyoming and southeastern Idaho. Bull. of the Geol. Soc. of Am. 53 937-996. https://doi.org/10.1130/gsab-53-937

Ochoa-González, R., Weiss, D., 2015. Zinc isotope variability in three coal-fired power plants: A predictive model for determining isotopic fractionation during combustion. Environ. Sci. Tech. 49 12560-12567. https://doi.org/10.1021/acs.est.5b02402

Paull, R. K., Paull, R. A. 1982. Permian-Triassic unconformity in the Terrace Mountains, northwestern Utah. Geology 10 582-587. https://doi.org/10.1130/00917613(1982) $10<582:$ puittm $>2.0 . c 0 ; 2$

Paull, R. K. Paull, R. A. 1994. Shallow marine sedimentary facies in the earliest Triassic (Griesbachian) Cordilleran miogeocline, U.S.A. Sediment. Geol. 93 181-191. https://doi.org/10.1016/0037-0738(94)90004-3

Payne, J.L., Clapham, M.E., 2012. End-Permian mass extinction in the oceans: an ancient analog for the twenty-first century? Ann. Rev. Earth Planet. Sci. 40 89-111. https://doi.org/10.1146/annurev-earth-042711-105329

Payne, J.L., Lehrmann, D.J., Follett, D., Seibel, M., Kump, L.R., Riccardi, A., Altiner, D., Sano, H., Wei, J., 2007. Erosional truncation of uppermost Permian shallow-marine carbonates and implications for Permian-Triassic boundary events. Geol. Soc. Am. Bull. 119771 784. https://doi.org/10.1130/b26091.1

Payne, J.L., Lehrmann, D.J., Wei, J., Orchard, M.J., Schrag, D.P., Knoll, A.H., 2004. Large perturbations of the carbon cycle during recovery from the end-Permian extinction. Science 305 506-509. https://doi.org/10.1126/science.1097023 
Peiffer, S., Behrends, T., Hellige, K., Larese-Casanova, P., Wan, M., Pollok, K., 2015. Pyrite formation and mineral transformation pathways upon sulfidation of ferric hydroxides depend on mineral type and sulfide concentrations. Chem. Geol. 400 44-55. https://doi.org/10.1016/j.chemgeo.2015.01.023

Rampino, M.R., Prokoph, A, Adler, A., 2000. Tempo of the end-Permian event: high-resolution cyclostratigraphy at the Permian-Triassic boundary. Geology 28 643-646. https://doi.org/10.1130/0091-7613(2000)028<0643:totepe $>2.3 . c 0 ; 2$

Rampino, M.R., Rodriguez, S., Baransky, E., Cai, Y. 2017. Global nickel anomaly links Siberian Traps eruptions and the latest Permian mass extinction. Scientific Reports 7, 12416. https://doi.org/10.1038/s41598-017-12759-9

Raup, D.M., 1979. Size of the Permo-Triassic bottleneck and its evolutionary implications. Science 206 217-218. https://doi.org/10.1126/science.206.4415.217

Reichow, M.K., Pringle, M.S., Al'Mukhamedov, A.I., Allen, M.B., Andreichev, V.L., Buslov, M.M., Davies, C.E., Fedoseev, G. S., Fitton, J.G., Inger, S., Medvedev, A.Y., Mitchell, C., Punchkov, V.N., Safonova, L.Y., Scott, R.A., Saunders, A. D., 2009, The timing and extent of the eruption of the Siberian Traps large igneous provinces: implications for the end-Permian environmental crisis. Earth Planet. Sci. Lett. 277 9-20. https://doi.org/10.1016/j.eps1.2008.09.030

Renne, P.R., Basu, A.R., 1991. Rapid eruption of the Siberian Traps flood basalts at the PermoTriassic boundary. Science 253 176-179. https://doi.org/10.1126/science.253.5016.176

Renne, P.R., Zichao, Z., Richards, M.A., Black, M.T., Basu, A.R., 1995, Synchrony and causal relations between Permian-Triassic boundary crises and Siberian flood volcanism. Science 269 1413-1416. https://doi.org/10.1126/science.269.5229.1413

Riccardi, A., Kump, L.R., Arthur, M.A., D’Hondt, S., 2007. Carbon isotopic evidence for chemocline upward excursions during the end-Permian event. Palaeogeogr. Palaeoclimatol. Palaeoecol. 248 73-81. https://doi.org/10.1016/j.palaeo.2006.11.010

Rickard, D. 1997. Kinetics of pyrite formation by the $\mathrm{H}_{2} \mathrm{~S}$ oxidation of iron (II) monosulfide in aqueous solutions between 25 and $125^{\circ} \mathrm{C}$ : the rate equation. Geochim. Cosmochim. Acta 61 115-134. https://doi.org/10.1016/s0016-7037(96)00321-3

Romano, C., Koot, M.B., Kogan, I., Brayard, A., Minikh, A.V., Brinkmann, W., Bucher, H., Kriwet, J., 2016. Permian-Triassic Osteichthyes (bony fishes) diversity dynamics and body size evolution. Biol. Rev. 91 106-147. https://doi.org/10.1111/brv.12161

Sanei, H., Grasby, S.E., Beauchamp, B. 2012. Latest Permian mercury anomalies. Geology 40 63-66. https://doi.org/10.1130/g32596.1

Schaeffer, B., 1973. "Fishes and the Permian-Triassic boundary" in The Permian and Triassic systems and their mutual boundary, Mem. of the Canadian Soc. of Petro. Geol. 2 493487. 
Schoepfer, S.D., Henderson, C.M., Garrison, G.H., Foriel, J., Ward, P.D., Selby, D., Hower, J.C., Algeo, T.J., Shen, Y., 2013. Termination of a continent-margin upwelling system at the Permian-Triassic boundary (Opal Creek, Alberta, Canada). Global Planet. Change 105 21-35. https://doi.org/10.1016/j.gloplacha.2012.07.005

Schoepfer, S.D., Henderson, C.M., Garrison, G.H., Ward, P.D., 2012. Cessation of a productive coastal upwelling system in the Pathalassic Permian-Triassic boundary. Palaeogeogr. Palaeoclimatol. Palaeoecol. 313-314 181-188. https://doi.org/10.1016/j.palaeo.2011.10.019

Schubert, J. K. Bottjer, D. J. 1995. Aftermath of the Permian-Triassic mass extinction event: Paleoecology of lower Triassic carbonates in the western USA. Palaeogeogr. Palaeoclimatol. Palaeoecol. 116 1-39. https://doi.org/10.1016/0031-0182(94)00093-n

Sheldon, N.D., 2006. Abrupt chemical weathering increase across the Permian-Triassic boundary. Palaeogeogr. Palaeoclimatol. Palaeoecol. 231 315-321. https://doi.org/10.1016/j.palaeo.2005.09.001

Shen, S.-Z., Crowley, J.L., Wang, Y., Bowring, S.A., Erwin, D.H., PSadler, P.M., Cao, C.-Q., Rothman, D.H., Henderson, C.M., Ramezani, J., Zhang, H., Shen, Y., Wang, X.-D. Wang, W., Mu, L., Li, W.-Z. Tang, Y.-G., Liu, X.-L., Liu, L.-J., Zeng, Y., Jin, Y.-G., 2011. Calibrating the end-Permian mass extinction. Science 334 1367-1372. https://doi.org/10.1126/science.1213454

Shen, W., Lin, Y., Xu, L., Li, J., Wu, Y., Sun, Y., 2007. Pyrite framboids in the Permian-Triassic boundary section at Meishan, China: evidence for dysoxic deposition. Palaeogeogr. Palaeoclimatol. Palaeoecol. 253 323-331. https://doi.org/10.1016/j.palaeo.2007.06.005

Smichowski, P., Gómez, D., Rosa, S., Polla, G., 2003. Trace elements content in size-classified volcanic ashes as determined by inductively coupled plasma-mass spectrometry. Microchem. Journal 75 109-117. https://doi.org/10.1016/s0026-265x(03)00089-4

Song, H., Tong, J., Algeo, T.J., Horacek, M., Qiu, H., Song, H., Tian, L., Chen, Z-Q., 2013. Large vertical $\delta^{13} C_{\text {DIC }}$ gradients in Early Triassic seas of the south China craton: implications for oceanographic changes related to Siberian Traps volcanism. Global Planet. Change 105 7-20. https://doi.org/10.1016/j.gloplacha.2012.10.023

Song, H., Tong, J., Chen, Z.Q., 2009. Two episodes of foraminiferal extinction near the PermianTriassic boundary at the Meishan section, south China. Australian J. Earth Sci. 56 765773. https://doi.org/10.1080/08120090903002599

Song, H., Wignall, P.B., Chu, D., Tong, J., Sun, Y., Song, H., He, W., Tian, L., 2014.Anoxia/high temperature double whammy during the Permian-Triassic marine crisis and its aftermath. Scientific Reports 44132 1-7. https://doi.org/10.1038/srep04132

Song, H., Wignall, P.B., Tong, J., Bond, D.P.G., Song, H., Lai, X., Zhang, K., Wang, H., Chen, Y., 2012. Geochemical evidence from bio-apatite for multiple oceanic anoxic events during Permian-Triassic transition and the link with end-Permian extinction and 
recovery. Earth Planet. Sci. Lett. 353-354 12-21.

https://doi.org/10.1016/j.epsl.2012.07.005

Sperling, E. A., Ingle, J. C. 2006. A Permian-Triassic boundary section at Quinn River Crossing, northwestern Nevada, and implications for the cause of the early Triassic chert gap on the western Pangean margin. Geol. Soc. Am. Bull.118 733-746. https://doi.org/10.1130/b25803.1

Sprinkel, D.A., Park, B., Stevens, M., 2000. Geological road guide to Sheep Creek Canyon geological area, northeastern Utah. Utah Geol. Association 29 1-14. https://www.utahgeology.org/road_logs/uga-29_first_edition/...guide/sheepcrk.pdf

Straub, M. Sigman, D.M., Ren, H., Martinez-Garcia, A., Meckler, A.N., Hain, M.P., Haung, G.H., 2013. Changes in North Atlantic nitrogen fixation controlled by ocean circulation. Nature 501 200-203. https://doi:10.1038/nature12397

Sun, Y., Joachimski, M.M., Wignall, P.B., Yan, C., Chen, Y., Jiang, H., Wang, L., Lai, X., 2012. Lethally hot temperatures during the early Triassic greenhouse. Science 338 366-370. https://doi.org/10.1126/science.1224126

Svensen, H., Planke, S., Polozov, A.G., Schmidbauer, N., Corfu, F., Podladchikov, Y.Y., Jamtveit, B., 2009. Siberian gas venting and the end-Permian environmental crisis. Earth Planet. Sci. Lett. 277 490-500. https://doi.org/10.1016/j.epsl.2008.11.015

Szmytkiewicz, A., Zalewska, T., 2014. Sediment deposition and accumulation rates determined by sediment trap and ${ }^{210} \mathrm{~Pb}$ isotope methods in the Outer Puck Bay (Baltic Sea).

Oceanologia 56 85-106. https://doi.org/10.5697/oc.56-1.085

Taylor, H.E., F. E. Lichte, F.E., 1980. Chemical composition of Mount St. Helens volcanic ash. Geophys. Res. Lett. 7 949-952. https://doi.org/10.1029/g1007i011p00949

Tian, L., Tong, J., Algeo, T.J., Song, H., Chu, D., Shi, L., Bottjer, D.J., 2014. Reconstruction of early Triassic ocean redox conditions based on framboidal pyrite from the Nanpanjiang Basin, south China. Palaeogeogr. Palaeoclimatol. Palaeoecol. 412 68-79. https://doi.org/10.1016/j.palaeo.2014.07.018

Torres, M.E., Brumsack, H.J., Bohrmann, G., Emeis, K.C., 1996. Barite fronts in continental margin sediments: A new look at barium remobilization in the zone of sulfate reduction and formation of heavy barites in diagenetic fronts. Chem. Geology. 127, 125-139. https://doi.org/10.1016/0009-2541(95)00090-9

Valentine, J.W., 1986. The Permian-Triassic extinction event and invertebrate developmental modes. Bull. Mar. Sci. 39 607-615.

Wang, K., Geldsetzer, H.H.J., Krouse, H.R., 1994. Permian-Triassic extinction: organic $\delta^{13} \mathrm{C}$ evidence from British Columbia, Canada. Geology 22 580-584. https://doi.org/10.1130/0091-7613(1994)022<0580:pteoce $>2.3 . c 0 ; 2$ 
Wang, G., Zhang,R., Gomez, M.E., Yang, L., Zamora, M.L., Hu, M., Lin, Y., Peng, J., Guo, S., Meng, J., Li, J., Cheng, C., Hu,T., Ren, Y., Wang, Y., Gao, J., Cao, J., An, Z., Zhou, W., Li, G., Wang, J., Tian, P., Marrero-Ortiz, W., Secrest, J., Du, Z., Zheng, J., Shang, D., Zeng, L., Shao, M., Wang, W., Huang, Y., Wang, Y., Zhu, Y., Li, Y., Hu, J., Pan, B., Cai, L., Cheng, Y., Ji, Y., Zhang, F., Rosenfeld, D., Liss, P.S., Duce, R.A., Kolb, C.E., Molina, M.J., 2016. Persistent sulfate formation from London Fog to Chinese haze. Proc. Natl. Acad. Sci. U.S.A. 113 13630-13635. https://doi.org/10.1073/pnas.1616540113

Wardlaw, B.R., Collinson, J.W., 1979. Biostratigraphic zonation of the Park City Group. U.S. Geol. Surv. Prof. Paper 1163-D 17-22.

Wardlaw, B.R., Collinson, J.W., 1986. Paleontology and deposition of the Phosphoria Formation. Contrib. Geology 24 107-142.

Wignall, P.B., 2007. The end-Permian mass extinction - how bad did it get? Geobiology 5 303309. https://doi.org/10.1111/j.1472-4669.2007.00130.x

Wignall, P. B., Hallam, A. 1992. Anoxia as a cause of the Permian/Triassic mass extinction: facies evidence from northern Italy and the western United States. Palaeogeogr. Palaeoclimatol. Palaeoecol. 93 21-45. https://doi.org/10.1016/0031-0182(92)90182-5

Wignall, P.B., Newton, R., Brookfield, M.E., 2005. Pyrite framboid evidence for oxygen-poor deposition during the Permian-Triassic crisis in Kashmir. Palaeogeogr. Palaeoclimatol. Palaeoecol. 216 183-188. https://doi.org/10.1016/j.palaeo.2004.10.009

Wignall, P.B., Twitchett, R.J., 2002. "Extent, duration, and nature of the Permian-Triassic superanoxic event" in Catastrophic Events and Mass Extinctions: Impacts and Beyond C. Koeberl, K. G. MacLeod Eds. (GSA Special Paper), 356, pp. 395-413. https://doi.org/10.1130/0-8137-2356-6.395

Winguth, A. Winguth, C., 2013. Precession-driven monsoon variability at the Permian-Triassic boundary- implications for anoxia and the mass extinction. Global Planet. Change $\mathbf{1 0 5}$ 160-170. https://doi.org/10.1016/j.gloplacha.2012.06.006

Xie, S., Pancost, R.D., Huang, J., Wignall, P.B., Yu, J., Tang, X., Chen, L., Huang, X., Lai, X., 2007. Changes in the global carbon cycle occurred as two episodes during the PermianTriassic crisis. Geology 35 1083-1086. https://doi.org/10.1130/g24224a.1

Xie, S., Pancost, R.D., Yin, H., Wang, H., Evershed, R.P., 2005. Two episodes of microbial change coupled with Permo/Triassic faunal mass extinction. Nature 434 494-497. https://doi.org/10.1038/nature03396

Xu, L., Lin, Y., Shen, W., Qi, L., Xie, L., Ouyang, Z., 2007. Platinum-group elements of the Meishan Permian-Triassic boundary section: evidence for flood basaltic volcanism. Chem. Geol. 246 55-64. https://doi.org/10.1016/j.chemgeo.2007.08.013

Zachos, J.C. Röhl, U., Schellenberg, S.A., Sluijs, A., Hodell, D.A., Kelly, D.C., Thomas, E., Nicolo, M., Raffi, I., Lourens, L.J., McCarren, H., Kroon, D., 2005. Rapid acidification 
of the ocean during the Paleocene-Eocene Thermal Maximum. Science 308 1611-1615. https://doi.org/10.1126/science.1109004

Zhang, G., Zhang, X., Hu, D., Li, D., Algeo, T.J., Farquhar, J., Henderson, C.M., Qin, L., Shen, M., Shen, D., Schoepfer, S.D., Chen, K., Shen, Y., 2017. Redox chemistry changes in the Panthalassic Ocean linked to the end-Permian mass extinction and delayed early Triassic biotic recovery. Proc. Natl. Acad. Sci. U.S.A. 114 1806-1810. https://doi.org/10.1073/pnas.1610931114

\section{SUPPLEMENTARY MATERIALS}

Table S1: Sample descriptions and $\mathrm{CaCO}_{3} \%$

Table S2: Results of Element Analysis (TOC\%, N\%, and S\%)

Table S3: Results of $\delta^{13} \mathrm{C}$ and $\delta^{18} \mathrm{O}$ in Carbonate Analysis (V-PDB)

Table S4: Results of Mercury Analysis (Hg ppm)

Table S5: Results of ICP-MS Analysis Siderophile Elements (Mn, Fe, Co, Ni, Pd, Pt)

Table S6: Results of ICP-MS Analysis Chalcophile Elements ( $\mathrm{Cu}, \mathrm{Zn}, \mathrm{Ga}, \mathrm{Pb})$

Table S7: Results of ICP-MS Analysis Lithophile Elements (Ti, V, Cr, Rb, Sr, Ba, La, Ce, Eu,

U) 
Table S1: Sample descriptions and $\mathrm{CaCO}_{3} \%$

\begin{tabular}{|c|c|c|c|c|c|c|c|c|}
\hline $\begin{array}{c}\text { Position } \\
\text { (cm) }\end{array}$ & Sample & $\begin{array}{c}\text { Color } \\
\text { (Munsell) }\end{array}$ & Minerals & $\begin{array}{c}\text { Sed. } \\
\text { Structures }\end{array}$ & Breakage & Type & $\begin{array}{c}\mathrm{CaCO}_{3} \\
\mathrm{kPa}\end{array}$ & $\begin{array}{l}\mathrm{CaCO}_{3} \\
\% \text { wt. }\end{array}$ \\
\hline 450 & TR-450 & $5 Y 8 / 1$ & $\begin{array}{l}\sim 10 \mathrm{~mm} \\
\text { pyrite } \\
\text { nodules }\end{array}$ & & Platy & Shale & 25 & 55 \\
\hline 350 & TR-350 & $5 Y 8 / 1$ & $\begin{array}{l}\sim 5 \mathrm{~mm} \\
\text { pyrite } \\
\text { nodules }\end{array}$ & & Platy & Shale & 34 & 64 \\
\hline 300 & TR-300 & $5 Y 8 / 1$ & $\begin{array}{l}\sim 1 \mathrm{~mm} \\
\text { pyrite } \\
\text { nodules }\end{array}$ & & Blocky & Mudstone & 35 & 65 \\
\hline 250 & TR-250 & 10YR 7/4 & $\begin{array}{l}\text { Hematite } \\
\text { veins }\end{array}$ & & Platy & Shale & 24 & 54 \\
\hline 200 & TR-200 & $5 Y 8 / 1$ & & $\begin{array}{l}\text { bi- } \\
\text { directional } \\
\text { cross } \\
\text { laminae }\end{array}$ & Platy & Shale & 22 & 52 \\
\hline 195 & TR-195 & $5 Y 8 / 1$ & $\begin{array}{l}\sim 3 \mathrm{~mm} \\
\text { pyrite } \\
\text { nodules }\end{array}$ & $\begin{array}{l}\text { bi- } \\
\text { directional } \\
\text { cross } \\
\text { laminae }\end{array}$ & Platy & Shale & 25 & 55 \\
\hline 190 & TR-190 & $5 Y 8 / 1$ & & & Platy & Shale & 40 & 69 \\
\hline 185 & TR-185 & $5 Y 8 / 1$ & $\begin{array}{l}\sim 1 \mathrm{~mm} \\
\text { pyrite } \\
\text { nodules }\end{array}$ & & Blocky & Mudstone & 30 & 60 \\
\hline 180 & TR-180 & $5 Y 8 / 1$ & & & Blocky & Mudstone & 30 & 60 \\
\hline 175 & TR-175 & $5 Y 8 / 1$ & & $\begin{array}{l}\text { bi- } \\
\text { directional } \\
\text { cross } \\
\text { laminae }\end{array}$ & Platy & Shale & 36 & 66 \\
\hline 170 & TR-170 & $5 Y 8 / 1$ & & $\begin{array}{l}\text { bi- } \\
\text { directional } \\
\text { cross } \\
\text { laminae }\end{array}$ & Platy & Shale & 30 & 60 \\
\hline 165 & TR-165 & $5 Y 8 / 1$ & & & Blocky & Mudstone & 25 & 55 \\
\hline 160 & TR-160 & $5 Y 8 / 1$ & & & Platy & Shale & 30 & 60 \\
\hline 155 & TR-155 & $5 Y 8 / 1$ & & & Platy & Shale & 30 & 60 \\
\hline 150 & TR-150 & $5 Y 8 / 1$ & $\begin{array}{l}\sim 5 \mathrm{~mm} \\
\text { pyrite } \\
\text { nodules }\end{array}$ & & Platy & Shale & 38 & 68 \\
\hline 145 & TR-145 & $5 Y 8 / 1$ & $\begin{array}{l}\sim 10 \mathrm{~mm} \\
\text { pyrite } \\
\text { nodules } \\
\end{array}$ & & Platy & Shale & 30 & 60 \\
\hline 140 & TR-140 & $5 Y 8 / 1$ & $\begin{array}{l}\sim 10 \mathrm{~mm} \\
\text { pyrite } \\
\text { nodules }\end{array}$ & & Platy & Shale & 38 & 68 \\
\hline 135 & TR-135 & $5 Y 8 / 1$ & $\begin{array}{l}\sim 1 \mathrm{~mm} \\
\text { pyrite } \\
\text { nodules }\end{array}$ & & Platy & Shale & 38 & 68 \\
\hline
\end{tabular}




\begin{tabular}{|c|c|c|c|c|c|c|c|c|}
\hline 130 & TR-130 & $5 Y 8 / 1$ & $\begin{array}{l}\text { Hematite } \\
\text { Limonite } \\
\text { Gypsum }\end{array}$ & $\begin{array}{l}\text { bi- } \\
\text { directional } \\
\text { cross } \\
\text { laminae }\end{array}$ & Platy & Shale & 30 & 60 \\
\hline 125 & TR-125 & $5 Y 8 / 1$ & & & Blocky & Mudstone & 20 & 50 \\
\hline 120 & TR-120 & $5 Y 8 / 1$ & $\begin{array}{l}\sim 2 \mathrm{~mm} \\
\text { pyrite } \\
\text { nodules }\end{array}$ & & Blocky & Mudstone & 38 & 68 \\
\hline 115 & TR-115 & $5 Y 8 / 1$ & $\begin{array}{l}\sim 3 \mathrm{~mm} \\
\text { pyrite } \\
\text { nodules }\end{array}$ & & Blocky & Mudstone & 30 & 60 \\
\hline 110 & TR-110 & $5 Y 8 / 1$ & & & Blocky & Mudstone & 30 & 60 \\
\hline 105 & TR-105 & $5 Y 8 / 1$ & & & Blocky & Mudstone & 15 & 45 \\
\hline 100 & TR-100 & $5 Y 8 / 1$ & & & Blocky & Mudstone & 40 & 69 \\
\hline 95 & TR-95 & $5 Y 8 / 1$ & & & Blocky & Mudstone & 38 & 68 \\
\hline 90 & TR-90 & $5 Y 8 / 1$ & & & Blocky & Mudstone & 44 & 72 \\
\hline 85 & TR-85 & $5 Y 8 / 1$ & $\begin{array}{l}\text { Hematite } \\
\text { Limonite }\end{array}$ & & Blocky & Mudstone & 35 & 65 \\
\hline 80 & TR-80 & $5 Y 8 / 1$ & & & Platy & Shale & 38 & 68 \\
\hline 75 & TR-75 & $5 Y 8 / 1$ & & & Platy & Shale & 30 & 60 \\
\hline 70 & TR-70 & $5 Y 8 / 1$ & $\begin{array}{l}\sim 5 \mathrm{~mm} \\
\text { pyrite } \\
\text { nodules }\end{array}$ & & Platy & Shale & 35 & 65 \\
\hline 65 & TR-65 & $5 Y 8 / 1$ & & & Blocky & & 27 & 56 \\
\hline 60 & TR-60 & $5 Y 8 / 1$ & & $\begin{array}{l}\text { bi- } \\
\text { directional } \\
\text { cross } \\
\text { laminae }\end{array}$ & Platy & Shale & 30 & 60 \\
\hline 55 & TR-55 & 10YR $6 / 2$ & & & Blocky & Mudstone & 24 & 54 \\
\hline 50 & TR-50 & 10YR $6 / 2$ & & & Blocky & Mudstone & 25 & 55 \\
\hline 45 & TR-45 & 10YR $7 / 4$ & & & Blocky & Mudstone & 25 & 55 \\
\hline 40 & TR-40 & 10YR $7 / 4$ & & & Blocky & Mudstone & 40 & 68 \\
\hline 35 & TR-35 & 10YR $7 / 4$ & & & Blocky & Mudstone & 28 & 58 \\
\hline 30 & TR-30 & 10YR 7/4 & & & Blocky & Mudstone & 25 & 55 \\
\hline 25 & TR-25 & 10YR 7/4 & & & Blocky & Mudstone & 35 & 64 \\
\hline 20 & TR-20 & 10YR $7 / 4$ & & & Blocky & Mudstone & 30 & 60 \\
\hline 15 & TR-15 & 10YR $7 / 4$ & & & Blocky & Mudstone & 42 & 70 \\
\hline 10 & TR-10 & 10YR 7/4 & & & Blocky & Mudstone & 49 & 76 \\
\hline 5 & TR-5 & 10YR $7 / 4$ & & & Blocky & Mudstone & 32 & 62 \\
\hline 0 & TR-0 & 10YR $7 / 4$ & & & Blocky & Mudstone & 20 & 50 \\
\hline 0 & $\mathrm{P}-0$ & $5 Y R 7 / 2$ & & & Hard & Limestone & 40 & 70 \\
\hline-5 & $P-5$ & $5 Y 8 / 1$ & $\begin{array}{l}\text { Small } \\
\text { specks of } \\
\text { Hematite }\end{array}$ & & Hard & Limestone & 70 & 89 \\
\hline-10 & P-10 & $5 Y 8 / 1$ & & & Hard & Limestone & 65 & 85 \\
\hline-15 & P-15 & $5 Y 8 / 1$ & & & Hard & Limestone & 75 & 94 \\
\hline-20 & $\mathrm{P}-20$ & $5 Y 8 / 1$ & & & Hard & Limestone & 60 & 82 \\
\hline-25 & $\mathrm{P}-25$ & $5 Y 8 / 1$ & & & Hard & Limestone & 66 & 86 \\
\hline
\end{tabular}




\begin{tabular}{|l|l|l|l|l|l|l|l|l|}
\hline-30 & $\mathrm{P}-30$ & $5 Y 8 / 1$ & & & Hard & Limestone & 66 & 86 \\
\hline-35 & $\mathrm{P}-35$ & $5 Y 8 / 1$ & & & Hard & Limestone & 59 & 81 \\
\hline-40 & $\mathrm{P}-40$ & $5 Y 8 / 1$ & & & Hard & Limestone & 52 & 78 \\
\hline-45 & $\mathrm{P}-45$ & $5 Y 8 / 1$ & & & Hard & Limestone & NA & NA \\
\hline-50 & $\mathrm{P}-50$ & $5 Y 8 / 1$ & & & Hard & Limestone & 70 & 88 \\
\hline-150 & $\mathrm{P}-150$ & $5 Y 8 / 1$ & & & Hard & Limestone & NA & NA \\
\hline-250 & $\mathrm{P}-250$ & $5 Y 8 / 1$ & & & Hard & Limestone & NA & NA \\
\hline-350 & $\mathrm{P}-350$ & $5 Y 8 / 1$ & & & Hard & Limestone & NA & NA \\
\hline-450 & $\mathrm{P}-450$ & $5 Y 8 / 1$ & & & Hard & Limestone & NA & NA \\
\hline
\end{tabular}


Table S2: Results of Element Analysis (TOC\%, N\%, and S\%)

\begin{tabular}{|l|l|l|l|l|}
\hline $\begin{array}{c}\text { Position } \\
(\mathbf{c m})\end{array}$ & Sample & TOC\% & \multicolumn{1}{|c|}{$\mathbf{N} \%$} & \multicolumn{1}{|c|}{$\mathbf{~} \%$} \\
\hline 450 & TR-450 & 2.863 & 0.0216 & 0 \\
\hline 350 & TR-350 & 2.045 & 0.0244 & 0.861 \\
\hline 300 & TR-300 & 2.398 & 0.0213 & 2.175 \\
\hline 250 & TR-250 & 2.498 & 0.0307 & 0 \\
\hline 200 & TR-200 & 2.483 & 0.0198 & 0 \\
\hline 195 & TR-195 & 3.001 & 0.0102 & 2.547 \\
\hline 190 & TR-190 & 3.034 & 0.0099 & 0 \\
\hline 185 & TR-185 & 2.917 & 0.0102 & 0 \\
\hline 180 & TR-180 & 4.040 & 0.0129 & 0 \\
\hline 175 & TR-175 & 5.138 & 0.0125 & 0 \\
\hline 170 & TR-170 & 4.601 & 0.0102 & 0 \\
\hline 165 & TR-165 & 5.278 & 0.0144 & 0 \\
\hline 160 & TR-160 & 4.297 & 0.0155 & 0 \\
\hline 155 & TR-155 & 3.647 & 0.0147 & 0 \\
\hline 150 & TR-150 & 3.602 & 0.0167 & 0 \\
\hline 145 & TR-145 & 3.427 & 0.0141 & 0 \\
\hline 140 & TR-140 & 3.369 & 0.0137 & 0.1271 \\
\hline 135 & TR-135 & 3.564 & 0.0162 & 0 \\
\hline 130 & TR-130 & 3.251 & 0.0124 & 0 \\
\hline 125 & TR-125 & 3.006 & 0.0187 & 0 \\
\hline 120 & TR-120 & 3.511 & 0.0182 & 0 \\
\hline 115 & TR-115 & 3.315 & 0.0148 & 0.0347 \\
\hline 110 & TR-110 & 3.509 & 0.0130 & 0 \\
\hline 105 & TR-105 & 3.890 & 0.0181 & 0 \\
\hline 100 & TR-100 & 3.541 & 0.0143 & 0 \\
\hline 95 & TR-95 & 4.184 & 0.0165 & 0 \\
\hline 90 & TR-90 & 4.046 & 0.0169 & 0 \\
\hline 85 & TR-85 & 3.497 & 0.0190 & 0 \\
\hline 80 & TR-80 & 3.487 & 0.0170 & 0 \\
\hline 75 & TR-75 & 3.545 & 0.0187 & 0 \\
\hline 70 & TR-70 & 2.536 & 0.0176 & 0.0614 \\
\hline 65 & TR-65 & 3.298 & 0.0144 & 0 \\
\hline 60 & TR-60 & 3.073 & 0.0135 & 0 \\
\hline 55 & TR-55 & 3.217 & 0.0142 & 0 \\
\hline 50 & TR-50 & 3.101 & 0.0161 & 0 \\
\hline 45 & TR-45 & 2.596 & 0.0151 & 0 \\
\hline 40 & TR-40 & 3.249 & 0.0187 & 0 \\
\hline 35 & TR-35 & 2.977 & 0.0168 & 0 \\
\hline & & & & \\
\hline
\end{tabular}




\begin{tabular}{|l|l|l|l|l|}
\hline 30 & TR-30 & 2.932 & 0.0192 & 0 \\
\hline 25 & TR-25 & 3.179 & 0.0187 & 0 \\
\hline 20 & TR-20 & 3.281 & 0.0190 & 0 \\
\hline 15 & TR-15 & 3.296 & 0.0198 & 0 \\
\hline 10 & TR-10 & 3.498 & 0.0189 & 0 \\
\hline 5 & TR-5 & 4.443 & 0.0200 & 0 \\
\hline 0 & TR-0 & 5.668 & 0.0153 & 0 \\
\hline 0 & P-0 & 11.29 & 0 & 0 \\
\hline-5 & P-5 & 15.23 & 0.0134 & 0 \\
\hline-10 & P-10 & 15.52 & 0.0135 & 0 \\
\hline-15 & P-15 & 15.30 & 0.0473 & 0 \\
\hline-20 & P-20 & 14.58 & 0.0302 & 0 \\
\hline-25 & P-25 & 14.51 & 0.0285 & 0 \\
\hline-30 & P-30 & 14.63 & 0.0091 & 0 \\
\hline-35 & P-35 & 13.84 & 0 & 0 \\
\hline-40 & P-40 & 14.34 & 0 & 0 \\
\hline-45 & P-45 & NA & NA & NA \\
\hline-50 & P-50 & 15.52 & 0 & 0 \\
\hline-150 & P-150 & NA & NA & NA \\
\hline-250 & P-250 & NA & NA & NA \\
\hline-350 & P-350 & NA & NA & NA \\
\hline-450 & P-450 & NA & NA & NA \\
\hline NA = Not Analyzed & & \\
\hline
\end{tabular}


Table S3: Results of $\delta^{13} \mathrm{C}$ and $\delta^{18} \mathrm{O}$ in Carbonate Analysis (V-PDB)

\begin{tabular}{|l|l|l|l|l|l|l|}
\hline $\begin{array}{c}\text { Position } \\
\mathbf{( c m )}\end{array}$ & Sample & $\begin{array}{c}\boldsymbol{1} \\
{ }^{13} \mathbf{C} /{ }^{12} \mathbf{C}\end{array}$ & \multicolumn{1}{|c|}{$\mathbf{s t d e v}$} & $\begin{array}{c}\boldsymbol{\delta} \\
{ }^{18} \mathbf{O} \mathbf{}^{16} \mathbf{O}\end{array}$ & $\mathbf{s t d e v}$ & $\mathbf{n}$ \\
\hline 450 & TR-450 & -2.034 & 0.11 & -4.194 & 0.15 & 8 \\
\hline 350 & TR-350 & -1.290 & 0.02 & -2.610 & 0.03 & 8 \\
\hline 300 & TR-300 & -1.290 & 0.02 & -2.350 & 0.02 & 8 \\
\hline 250 & TR-250 & -1.559 & 0.04 & -2.589 & 0.21 & 8 \\
\hline 200 & TR-200 & -0.610 & 0.02 & -3.100 & 0.02 & 8 \\
\hline 195 & TR-195 & -2.870 & 0.03 & -6.140 & 0.03 & 8 \\
\hline 190 & TR-190 & -3.627 & 0.11 & -7.095 & 0.04 & 4 \\
\hline 185 & TR-185 & -2.178 & 0.08 & -5.327 & 0.07 & 7 \\
\hline 180 & TR-180 & NA & NA & NA & NA & NA \\
\hline 175 & TR-175 & -2.470 & 0.01 & -5.990 & 0.03 & 8 \\
\hline 170 & TR-170 & -3.550 & 0.03 & -6.920 & 0.04 & 8 \\
\hline 165 & TR-165 & -1.770 & 0.01 & -5.480 & 0.04 & 8 \\
\hline 160 & TR-160 & -1.753 & 0.05 & -5.358 & 0.07 & 8 \\
\hline 155 & TR-155 & -2.010 & 0.09 & -5.439 & 0.14 & 8 \\
\hline 150 & TR-150 & -1.701 & 0.07 & -4.992 & 0.05 & 8 \\
\hline 145 & TR-145 & -2.057 & 0.06 & -5.439 & 0.06 & 8 \\
\hline 140 & TR-140 & -1.710 & 0.02 & -5.150 & 0.02 & 8 \\
\hline 135 & TR-135 & -1.790 & 0.02 & -5.300 & 0.02 & 8 \\
\hline 130 & TR-130 & -1.910 & 0.02 & -6.050 & 0.01 & 8 \\
\hline 125 & TR-125 & -1.580 & 0.03 & -5.860 & 0.02 & 8 \\
\hline 120 & TR-120 & -1.950 & 0.02 & -5.640 & 0.02 & 8 \\
\hline 115 & TR-115 & -1.548 & 0.10 & -4.804 & 0.13 & 8 \\
\hline 110 & TR-110 & -1.474 & 0.07 & -4.697 & 0.09 & 8 \\
\hline 105 & TR-105 & -1.627 & 0.04 & -6.778 & 0.05 & 7 \\
\hline 100 & TR-100 & -1.420 & 0.02 & -6.180 & 0.03 & 8 \\
\hline 95 & TR-95 & -1.010 & 0.01 & -5.070 & 0.02 & 8 \\
\hline 90 & TR-90 & -1.290 & 0.02 & -6.690 & 0.02 & 8 \\
\hline 85 & TR-85 & -0.367 & 0.10 & -3.872 & 0.07 & 8 \\
\hline 80 & TR-80 & -0.762 & 0.09 & -4.099 & 0.11 & 7 \\
\hline 75 & TR-75 & -0.850 & 0.05 & -5.390 & 0.11 & 5 \\
\hline 70 & TR-70 & -0.260 & 0.02 & -4.370 & 0.03 & 8 \\
\hline 65 & TR-65 & -0.630 & 0.03 & -5.210 & 0.05 & 8 \\
\hline 60 & TR-60 & 0.013 & 0.05 & -4.603 & 0.04 & 8 \\
\hline 55 & TR-55 & -0.142 & 0.12 & -4.408 & 0.12 & 8 \\
\hline 50 & TR-50 & 0.377 & 0.05 & -4.498 & 0.07 & 5 \\
\hline 50 & TR-50R & 0.205 & 0.05 & -4.194 & 0.07 & 8 \\
\hline 50 & TR-50 & 0.470 & 0.02 & -4.000 & 0.02 & 8 \\
\hline 45 & TR-45 & 1.031 & 0.16 & -3.377 & 0.14 & 8 \\
\hline & & & & & & \\
\hline
\end{tabular}




\begin{tabular}{|l|l|l|l|l|l|l|}
\hline 40 & TR-40 & 0.519 & 0.05 & -3.824 & 0.13 & 7 \\
\hline 35 & TR-35 & 0.692 & 0.09 & -3.704 & 0.12 & 6 \\
\hline 30 & TR-30 & 1.049 & 0.08 & -4.177 & 0.08 & 7 \\
\hline 25 & TR-25 & 1.843 & 0.03 & -4.916 & 0.08 & 8 \\
\hline 20 & TR-20 & 1.449 & 0.10 & -4.727 & 0.13 & 8 \\
\hline 15 & TR-15 & 1.675 & 0.07 & -4.091 & 0.08 & 8 \\
\hline 10 & TR-10 & 2.440 & 0.02 & -3.060 & 0.03 & 8 \\
\hline 5 & TR-5 & 2.097 & 0.06 & -3.877 & 0.08 & 8 \\
\hline 5 & TR-5R & 2.520 & 0.02 & -2.960 & 0.04 & 8 \\
\hline 0 & TR-0 & 2.203 & 0.05 & -2.607 & 0.08 & 8 \\
\hline 0 & P-0 & NA & NA & NA & NA & NA \\
\hline-5 & P-5 & 1.212 & 0.03 & -0.528 & 0.03 & 8 \\
\hline-10 & P-10 & 1.893 & 0.02 & 2.741 & 0.03 & 8 \\
\hline-15 & P-15 & NA & NA & NA & NA & NA \\
\hline-20 & P-20 & NA & NA & NA & NA & NA \\
\hline-25 & P-25 & 1.447 & 0.03 & 0.243 & 0.08 & 8 \\
\hline-30 & P-30 & 2.858 & 0.02 & 3.546 & 0.01 & 8 \\
\hline-35 & P-35 & 2.358 & 0.04 & 3.621 & 0.05 & 8 \\
\hline-40 & P-40 & 0.182 & 0.03 & -3.206 & 0.04 & 8 \\
\hline-45 & P-45 & NA & NA & NA & NA & NA \\
\hline-50 & P-50 & -0.972 & 0.04 & -1.643 & 0.03 & 8 \\
\hline-150 & P-150 & NA & NA & NA & NA & NA \\
\hline-250 & P-250 & NA & NA & NA & NA & NA \\
\hline-350 & P-350 & NA & NA & NA & NA & NA \\
\hline-450 & P-450 & NA & NA & NA & NA & NA \\
\hline & & & & & & \\
\hline
\end{tabular}


Table S4: Results of Mercury Analysis (Hg ppm)

\begin{tabular}{|l|l|r|r|}
\hline $\begin{array}{c}\text { Position } \\
\mathbf{( c m} \text { ) }\end{array}$ & Sample & $\begin{array}{c}\text { Hg } \\
\mathbf{( p p m )}\end{array}$ & Hg $\mathbf{( p p b ) / ~}$ TOC\% \\
\hline 450 & TR-450 & 0.00143 & 49.95 \\
\hline 350 & TR-350 & 0.00247 & 120.78 \\
\hline 300 & TR-300 & 0.00168 & 70.06 \\
\hline 250 & TR-250 & 0.00115 & 46.04 \\
\hline 200 & TR-200 & 0.00153 & 61.62 \\
\hline 195 & TR-195 & 0.00171 & 56.98 \\
\hline 190 & TR-190 & 0.00081 & 26.70 \\
\hline 185 & TR-185 & 0.00349 & 119.64 \\
\hline 180 & TR-180 & 0.00275 & 68.07 \\
\hline 175 & TR-175 & 0.00117 & 22.77 \\
\hline 170 & TR-170 & 0.00117 & 25.43 \\
\hline 165 & TR-165 & 0.00301 & 57.03 \\
\hline 160 & TR-160 & 0.00262 & 60.97 \\
\hline 155 & TR-155 & 0.00138 & 37.84 \\
\hline 150 & TR-150 & 0.00349 & 96.89 \\
\hline 145 & TR-145 & 0.00483 & 140.94 \\
\hline 140 & TR-140 & 0.00482 & 143.07 \\
\hline 135 & TR-135 & 0.00417 & 117.00 \\
\hline 130 & TR-130 & 0.00156 & 47.99 \\
\hline 125 & TR-125 & 0.00258 & 85.83 \\
\hline 120 & TR-120 & 0.00293 & 83.45 \\
\hline 115 & TR-115 & 0.00142 & 42.84 \\
\hline 110 & TR-110 & 0.00173 & 49.84 \\
\hline 105 & TR-105 & 0.00216 & 55.53 \\
\hline 100 & TR-100 & 0.00542 & 153.06 \\
\hline 95 & TR-95 & 0.00482 & 115.20 \\
\hline 90 & TR-90 & 0.00217 & 53.63 \\
\hline 85 & TR-85 & 0.00200 & 57.19 \\
\hline 80 & TR-80 & 0.00345 & 98.94 \\
\hline 75 & TR-75 & 0.00263 & 74.19 \\
\hline 70 & TR-70 & 0.01966 & 775.24 \\
\hline 65 & TR-65 & 0.01301 & 394.48 \\
\hline 60 & TR-60 & 0.00588 & 191.34 \\
\hline 55 & TR-55 & 0.00544 & 169.10 \\
\hline 50 & TR-50 & 0.00822 & 265.08 \\
\hline 45 & TR-45 & 0.00585 & 225.35 \\
\hline 40 & TR-40 & 0.00432 & 132.96 \\
\hline 35 & TR-35 & 0.01095 & 367.82 \\
\hline & & & \\
\hline
\end{tabular}




\begin{tabular}{|l|l|r|r|}
\hline 30 & TR-30 & 0.00437 & 149.05 \\
\hline 25 & TR-25 & 0.00418 & 131.49 \\
\hline 20 & TR-20 & 0.00684 & 208.47 \\
\hline 15 & TR-15 & 0.00731 & 221.78 \\
\hline 10 & TR-10 & 0.01334 & 381.36 \\
\hline 5 & TR-5 & 0.02324 & 523.07 \\
\hline 0 & TR-0 & 0.02095 & 369.62 \\
\hline 0 & P-0 & 0.01853 & 164.13 \\
\hline-5 & P-5 & 0.00306 & 20.09 \\
\hline-10 & P-10 & 0.00594 & 38.27 \\
\hline-15 & P-15 & 0.01196 & 78.17 \\
\hline-20 & P-20 & 0.00718 & 49.25 \\
\hline-25 & P-25 & 0.00694 & 47.83 \\
\hline-30 & P-30 & 0.00489 & 33.42 \\
\hline-35 & P-35 & 0.00488 & 35.26 \\
\hline-40 & P-40 & 0.00274 & 19.11 \\
\hline-45 & P-45 & NA & NA \\
\hline-50 & P-50 & 0.00229 & 14.76 \\
\hline-150 & P-150 & NA & NA \\
\hline-250 & P-250 & NA & NA \\
\hline-350 & P-350 & NA & NA \\
\hline-450 & P-450 & NA & \\
\hline & & & NA \\
\hline
\end{tabular}


Table S5: Results of ICP-MS Analysis Siderophile Elements (Mn, Fe, Co, Ni, Pd, Pt)

\begin{tabular}{|c|c|c|c|c|c|c|c|c|}
\hline $\begin{array}{l}\text { Position } \\
(\mathrm{cm})\end{array}$ & Sample & $\begin{array}{l}{ }^{55} \mathrm{Mn} \\
\text { (ppm) }\end{array}$ & $\begin{array}{c}{ }^{56} \mathrm{Fe} \\
\text { (ppm) }\end{array}$ & $\begin{array}{l}{ }^{59} \mathrm{Co} \\
\text { (ppm) }\end{array}$ & $\begin{array}{c}{ }^{60} \mathrm{Ni} \\
\text { (ppm) }\end{array}$ & $\begin{array}{c}{ }^{62} \mathrm{Ni} \\
\text { (ppm) }\end{array}$ & $\begin{array}{l}{ }^{105} \mathrm{Pd} \\
\text { (ppb) }\end{array}$ & $\begin{array}{l}{ }^{195} \mathrm{Pt} \\
\text { (ppb) }\end{array}$ \\
\hline 450 & TR-450 & 423.2 & 11318.1 & 6.2 & 14.2 & 23.6 & 0.0 & 0.003 \\
\hline 350 & TR-350 & 353.2 & 23595.1 & 12.3 & 28.7 & 39.2 & 0.0 & 0.003 \\
\hline 300 & TR-300 & 301.5 & 26893.3 & 4.7 & 19.7 & 28.9 & 0.0 & 0.004 \\
\hline 250 & TR-250 & 279.3 & 13663.0 & 3.8 & 12.6 & 21.9 & 0.0 & 0.003 \\
\hline 200 & TR-200 & 282.7 & 9633.0 & 3.2 & 12.6 & 22.6 & 0.0 & 0.003 \\
\hline 195 & TR-195 & 330.0 & 11690.0 & 2.8 & 9.4 & 14.7 & 0.0 & 0.002 \\
\hline 190 & TR-190 & 328.4 & 7317.8 & 3.2 & 8.3 & 13.9 & 0.0 & 0.002 \\
\hline 185 & TR-185 & 326.8 & 6093.0 & 3.0 & 9.6 & 16.9 & 0.0 & 0.005 \\
\hline 180 & TR-180 & 390.5 & 8216.1 & 3.2 & 8.4 & 15.6 & 0.0 & 0.004 \\
\hline 175 & TR-175 & 465.5 & 7519.8 & 4.3 & 9.0 & 14.9 & 0.0 & 0.005 \\
\hline 170 & TR-170 & 439.1 & 7152.2 & 3.9 & 7.1 & 13.4 & 0.0 & 0.007 \\
\hline 165 & TR-165 & 493.9 & 9124.8 & 4.6 & 10.7 & 16.8 & 0.0 & 0.003 \\
\hline 160 & TR-160 & 457.0 & 12547.6 & 5.7 & 16.1 & 23.8 & 0.0 & 0.003 \\
\hline 155 & TR-155 & 414.1 & 14819.2 & 5.6 & 15.0 & 21.9 & 0.0 & 0.007 \\
\hline 150 & TR-150 & 398.1 & 30634.0 & 5.9 & 15.8 & 22.9 & 0.0 & 0.009 \\
\hline 145 & TR-145 & 395.0 & 12403.8 & 4.0 & 10.7 & 18.2 & 0.0 & 0.007 \\
\hline 140 & TR-140 & 418.3 & 18336.2 & 4.6 & 15.1 & 23.6 & 0.0 & 0.006 \\
\hline 135 & TR-135 & 436.4 & 14550.0 & 6.2 & 15.9 & 22.4 & 0.0 & 0.007 \\
\hline 130 & TR-130 & 445.3 & 12348.9 & 5.9 & 16.6 & 24.2 & 0.0 & 0.006 \\
\hline 125 & TR-125 & 399.9 & 14173.3 & 5.3 & 15.3 & 23.3 & 0.0 & 0.007 \\
\hline 120 & TR-120 & 441.0 & 14376.7 & 5.5 & 13.3 & 21.4 & 0.0 & 0.005 \\
\hline 115 & TR-115 & 427.2 & 12376.1 & 5.1 & 16.5 & 24.5 & 0.0 & 0.006 \\
\hline 110 & TR-110 & 404.9 & 12347.9 & 4.8 & 12.8 & 19.7 & 0.0 & 0.009 \\
\hline 105 & TR-105 & 477.0 & 10241.1 & 8.6 & 17.0 & 23.8 & 0.0 & 0.007 \\
\hline 100 & TR-100 & 426.4 & 11053.1 & 5.8 & 17.9 & 25.8 & 0.0 & 0.008 \\
\hline 95 & TR-95 & 467.3 & 12682.9 & 6.2 & 17.9 & 26.8 & 0.1 & 0.005 \\
\hline 90 & TR-90 & 451.8 & 13002.0 & 6.3 & 17.4 & 25.4 & 0.0 & 0.011 \\
\hline 85 & TR-85 & 454.3 & 14970.5 & 7.2 & 17.0 & 25.9 & 0.0 & 0.005 \\
\hline 80 & TR-80 & 436.5 & 16771.4 & 6.6 & 17.7 & 27.4 & 0.0 & 0.007 \\
\hline 75 & TR-75 & 432.4 & 14810.8 & 7.0 & 16.6 & 26.4 & 0.0 & 0.005 \\
\hline 70 & TR-70 & 409.1 & 24899.7 & 9.5 & 28.2 & 37.0 & 0.0 & 0.009 \\
\hline 65 & TR-65 & 375.7 & 14041.9 & 5.9 & 18.6 & 26.4 & 0.0 & 0.008 \\
\hline 60 & TR-60 & 350.8 & 15115.9 & 5.8 & 21.0 & 28.5 & 0.0 & 0.009 \\
\hline 55 & TR-55 & 384.4 & 14952.9 & 6.6 & 23.4 & 32.7 & 0.3 & 0.005 \\
\hline 50 & TR-50 & 336.7 & 10914.5 & 6.8 & 23.7 & 32.0 & 0.2 & 0.009 \\
\hline 45 & TR-45 & 363.1 & 10558.3 & 6.0 & 15.0 & 26.3 & 0.6 & 0.008 \\
\hline 40 & TR-40 & 397.4 & 12816.3 & 7.4 & 16.0 & 27.8 & 0.9 & 0.007 \\
\hline 35 & TR-35 & 352.4 & 11791.3 & 7.8 & 19.3 & 29.4 & 0.8 & 0.009 \\
\hline
\end{tabular}




\begin{tabular}{|c|c|c|c|c|c|c|c|c|}
\hline 30 & TR-30 & 374.3 & 11298.9 & 7.6 & 20.4 & 32.0 & 0.7 & 0.008 \\
\hline 25 & TR-25 & 385.3 & 12903.4 & 9.0 & 25.0 & 36.1 & 0.8 & 0.007 \\
\hline 20 & TR-20 & 362.3 & 11540.4 & 8.5 & 21.2 & 30.9 & 0.9 & 0.009 \\
\hline 15 & TR-15 & 383.4 & 12781.1 & 8.6 & 22.0 & 32.6 & 0.8 & 0.010 \\
\hline 10 & TR-10 & 344.7 & 10514.9 & 7.5 & 18.6 & 26.6 & 0.2 & 0.012 \\
\hline 5 & TR-5 & 380.4 & 10563.6 & 5.7 & 12.7 & 20.6 & 1.0 & 0.015 \\
\hline 0 & TR-0 & 458.6 & 10258.9 & 5.7 & 11.9 & 17.7 & 1.5 & 0.011 \\
\hline 0 & $\mathrm{P}-0$ & 1018.0 & 57792.2 & 8.0 & 21.6 & 19.8 & 1.2 & 0.011 \\
\hline-5 & $P-5$ & 370.8 & 603.0 & 0.8 & 4.8 & 1.2 & 0.7 & 0.014 \\
\hline-10 & P-10 & 369.5 & 1220.5 & 1.1 & 4.6 & 1.8 & 1.0 & 0.015 \\
\hline-15 & P-15 & 400.0 & 1506.4 & 1.2 & 5.8 & 2.8 & 0.9 & 0.016 \\
\hline-20 & $\mathrm{P}-20$ & 467.7 & 2562.6 & 0.6 & 6.6 & 3.9 & 1.5 & 0.019 \\
\hline-25 & P-25 & 361.5 & 2384.2 & 1.6 & 7.2 & 5.2 & 1.0 & 0.030 \\
\hline-30 & P-30 & 393.6 & 2189.4 & 1.0 & 7.0 & 4.5 & 1.2 & 0.028 \\
\hline-35 & P-35 & 380.1 & 2569.7 & 1.0 & 7.4 & 4.8 & 1.3 & 0.035 \\
\hline-40 & $\mathrm{P}-40$ & 426.3 & 1259.7 & 1.3 & 5.3 & 2.0 & 1.0 & 0.040 \\
\hline-45 & $\mathrm{P}-45$ & NA & NA & NA & NA & NA & NA & NA \\
\hline-50 & P-50 & 350.0 & 1192.8 & 1.1 & 5.4 & 2.2 & 1.6 & 0.041 \\
\hline-150 & P-150 & NA & NA & NA & NA & NA & NA & NA \\
\hline-250 & P-250 & NA & NA & NA & NA & NA & NA & NA \\
\hline-350 & P-350 & NA & NA & NA & NA & NA & NA & NA \\
\hline-450 & P-450 & NA & NA & NA & NA & NA & NA & NA \\
\hline
\end{tabular}


Table S6: Results of ICP-MS Analysis Chalcophile Elements (Cu, Zn, Ga, Pb)

\begin{tabular}{|l|c|c|c|c|c|}
\hline $\begin{array}{c}\text { Position } \\
\mathbf{( c m}\end{array}$ & Sample & $\begin{array}{c}{ }^{65} \mathbf{C u} \\
\mathbf{( p p m )}\end{array}$ & $\begin{array}{c}{ }^{66} \mathbf{Z n} \\
\mathbf{( p p m )}\end{array}$ & $\begin{array}{c}{ }^{71} \mathbf{G a} \\
\mathbf{( p p m )}\end{array}$ & $\begin{array}{c}{ }^{\mathbf{2 0 8}} \mathbf{P b} \\
\mathbf{( p p m} \text { ) }\end{array}$ \\
\hline 450 & TR-450 & 14.1 & 32.6 & 11.2 & 1.2 \\
\hline 350 & TR-350 & 13.8 & 69.6 & 10.7 & 0.1 \\
\hline 300 & TR-300 & 19.3 & 42.4 & 8.7 & 5.5 \\
\hline 250 & TR-250 & 11.1 & 17.5 & 7.8 & 4.3 \\
\hline 200 & TR-200 & 7.8 & 36.7 & 10.6 & 0.0 \\
\hline 195 & TR-195 & 1.6 & 18.2 & 4.7 & 0.0 \\
\hline 190 & TR-190 & 2.8 & 15.0 & 5.0 & 0.0 \\
\hline 185 & TR-185 & 1.4 & 8.0 & 5.1 & 0.0 \\
\hline 180 & TR-180 & 5.2 & 12.6 & 6.2 & 0.7 \\
\hline 175 & TR-175 & 3.3 & 16.2 & 5.9 & 0.0 \\
\hline 170 & TR-170 & 1.4 & 15.8 & 4.8 & 0.0 \\
\hline 165 & TR-165 & 5.4 & 14.1 & 6.9 & 0.0 \\
\hline 160 & TR-160 & 5.2 & 32.1 & 7.3 & 0.0 \\
\hline 155 & TR-155 & 6.7 & 39.4 & 7.4 & 5.1 \\
\hline 150 & TR-150 & 11.8 & 41.3 & 8.1 & 10.9 \\
\hline 145 & TR-145 & 4.7 & 25.0 & 7.5 & 4.4 \\
\hline 140 & TR-140 & 7.8 & 40.7 & 7.3 & 2.1 \\
\hline 135 & TR-135 & 5.5 & 39.4 & 7.9 & 1.3 \\
\hline 130 & TR-130 & 6.7 & 31.1 & 6.9 & 5.0 \\
\hline 125 & TR-125 & 7.3 & 30.5 & 7.5 & 2.8 \\
\hline 120 & TR-120 & 5.4 & 29.6 & 9.1 & 0.0 \\
\hline 115 & TR-115 & 5.0 & 36.6 & 8.1 & 0.0 \\
\hline 110 & TR-110 & 4.6 & 26.3 & 7.8 & 5.7 \\
\hline 105 & TR-105 & 5.4 & 21.4 & 7.9 & 5.7 \\
\hline 100 & TR-100 & 6.7 & 31.1 & 7.6 & 6.7 \\
\hline 95 & TR-95 & 4.7 & 28.0 & 8.9 & 2.4 \\
\hline 90 & TR-90 & 7.7 & 33.8 & 8.6 & 0.0 \\
\hline 85 & TR-85 & 6.1 & 30.8 & 9.5 & 0.2 \\
\hline 80 & TR-80 & 8.5 & 34.4 & 9.4 & 8.1 \\
\hline 75 & TR-75 & 8.4 & 31.9 & 10.9 & 5.4 \\
\hline 70 & TR-70 & 21.6 & 65.4 & 9.7 & 14.8 \\
\hline 65 & TR-65 & 10.2 & 39.3 & 9.4 & 9.3 \\
\hline 60 & TR-60 & 7.0 & 42.7 & 8.7 & 12.4 \\
\hline 55 & TR-55 & 6.1 & 42.3 & 9.6 & 2.8 \\
\hline 50 & TR-50 & 6.8 & 33.8 & 11.0 & 8.7 \\
\hline 45 & TR-45 & 7.2 & 46.3 & 11.2 & 3.0 \\
\hline 40 & TR-40 & 8.2 & 51.8 & 13.0 & 5.7 \\
\hline 35 & TR-35 & 9.8 & 67.7 & 10.8 & 5.6 \\
\hline & & & & & \\
\hline
\end{tabular}




\begin{tabular}{|l|c|c|c|c|c|}
\hline 30 & TR-30 & 9.2 & 78.3 & 12.1 & 3.7 \\
\hline 25 & TR-25 & 11.3 & 87.4 & 12.4 & 8.9 \\
\hline 20 & TR-20 & 11.5 & 69.4 & 11.5 & 6.5 \\
\hline 15 & TR-15 & 13.1 & 80.0 & 12.8 & 11.2 \\
\hline 10 & TR-10 & 11.9 & 59.1 & 11.4 & 12.0 \\
\hline 5 & TR-5 & 11.2 & 59.2 & 11.0 & 14.7 \\
\hline 0 & TR-0 & 6.4 & 50.6 & 8.8 & 5.5 \\
\hline 0 & P-0 & 5.8 & 58.9 & 1.2 & 6.3 \\
\hline-5 & P-5 & 6.8 & 15.5 & 0.0 & 0.0 \\
\hline-10 & P-10 & 42.4 & 22.6 & 0.1 & 0.0 \\
\hline-15 & $P-15$ & 28.5 & 32.0 & 0.2 & 0.0 \\
\hline-20 & $P-20$ & 30.3 & 53.0 & 0.3 & 0.0 \\
\hline-25 & P-25 & 12.1 & 50.4 & 0.7 & 1.4 \\
\hline-30 & $P-30$ & 9.0 & 50.0 & 0.2 & 0.0 \\
\hline-35 & $P-35$ & 15.7 & 56.9 & 0.5 & 0.0 \\
\hline-40 & P-40 & 10.7 & 28.9 & 0.3 & 0.0 \\
\hline-45 & P-45 & NA & NA & NA & NA \\
\hline-50 & P-50 & 104.7 & 19.9 & 0.1 & 0.0 \\
\hline-150 & P-150 & NA & NA & NA & NA \\
\hline-250 & P-250 & NA & NA & NA & NA \\
\hline-350 & P-350 & NA & NA & NA & NA \\
\hline-450 & P-450 & NA & NA & NA & NA \\
\hline
\end{tabular}


Table S7: Results of ICP-MS Analysis Lithophile Elements (Ti, V, Cr, Rb, Sr, Ba, La, Ce, Eu,

U)

\begin{tabular}{|c|c|c|c|c|c|c|c|c|c|c|c|}
\hline $\begin{array}{l}\text { Pos. } \\
\text { (cm) }\end{array}$ & Sample & $\begin{array}{c}{ }^{47} \mathrm{Ti} \\
\text { (ppm) }\end{array}$ & $\begin{array}{c}{ }^{51} V \\
\text { (ppm) }\end{array}$ & $\begin{array}{c}{ }^{52} \mathrm{Cr} \\
\text { (ppm) }\end{array}$ & $\begin{array}{c}{ }^{85} \mathrm{Rb} \\
(\mathrm{ppm})\end{array}$ & $\begin{array}{c}{ }^{88} \mathrm{Sr} \\
\text { (ppm) }\end{array}$ & $\begin{array}{c}{ }^{137} \mathrm{Ba} \\
\text { (ppm) }\end{array}$ & $\begin{array}{l}{ }^{139} \mathrm{La} \\
\text { (ppm) }\end{array}$ & $\begin{array}{c}{ }^{140} \mathrm{Ce} \\
\text { (ppm) }\end{array}$ & $\begin{array}{l}{ }^{153} \mathrm{Eu} \\
(\mathrm{ppm})\end{array}$ & $\begin{array}{c}{ }^{238} U \\
\text { (ppm) }\end{array}$ \\
\hline 450 & $\begin{array}{l}\text { TR- } \\
450\end{array}$ & 2229.8 & 55.2 & 33.7 & 68.5 & 185.1 & 277.3 & 22.4 & 44.8 & 0.9 & 2.4 \\
\hline 350 & $\begin{array}{l}\text { TR- } \\
350\end{array}$ & 2457.4 & 52.9 & 39.9 & 63.3 & 184.9 & 277.6 & 24.8 & 50.6 & 0.9 & 2.6 \\
\hline 300 & $\begin{array}{l}\text { TR- } \\
300\end{array}$ & 2280.1 & 42.6 & 33.7 & 47.0 & 172.3 & 494.1 & 20.2 & 41.1 & 0.9 & 2.0 \\
\hline 250 & $\begin{array}{l}\text { TR- } \\
250\end{array}$ & 2238.8 & 45.1 & 30.3 & 43.0 & 200.0 & 373.7 & 19.0 & 38.5 & 0.8 & 2.2 \\
\hline 200 & $\begin{array}{l}\text { TR- } \\
200\end{array}$ & 2417.2 & 48.1 & 37.0 & 57.4 & 286.4 & 317.6 & 21.6 & 43.4 & 0.9 & 2.1 \\
\hline 195 & $\begin{array}{l}\text { TR- } \\
195\end{array}$ & 1381.1 & 28.3 & 16.1 & 28.9 & 207.6 & 647.7 & 14.5 & 29.9 & 0.7 & 1.4 \\
\hline 190 & $\begin{array}{l}\text { TR- } \\
190\end{array}$ & 1434.3 & 34.7 & 17.0 & 31.0 & 175.3 & 752.5 & 12.4 & 25.3 & 0.7 & 1.5 \\
\hline 185 & $\begin{array}{l}\text { TR- } \\
185 \\
\end{array}$ & 1840.8 & 27.1 & 19.0 & 32.1 & 172.2 & 282.3 & 14.5 & 28.8 & 0.6 & 1.7 \\
\hline 180 & $\begin{array}{l}\text { TR- } \\
180\end{array}$ & 1794.7 & 34.2 & 22.4 & 36.2 & 180.4 & 315.1 & 13.8 & 27.3 & 0.7 & 1.6 \\
\hline 175 & $\begin{array}{l}\text { TR- } \\
175\end{array}$ & 1706.5 & 36.3 & 24.0 & 34.3 & 335.5 & 556.8 & 19.4 & 41.4 & 1.0 & 2.0 \\
\hline 170 & $\begin{array}{l}\text { TR- } \\
170\end{array}$ & 1742.7 & 31.6 & 21.4 & 28.0 & 333.8 & 997.2 & 19.7 & 42.5 & 1.1 & 2.0 \\
\hline 165 & $\begin{array}{l}\text { TR- } \\
165\end{array}$ & 1779.0 & 40.3 & 31.4 & 41.1 & 262.9 & 255.0 & 16.3 & 31.9 & 0.8 & 1.8 \\
\hline 160 & $\begin{array}{l}\text { TR- } \\
160\end{array}$ & 2032.2 & 38.0 & 27.3 & 43.0 & 194.4 & 290.6 & 15.2 & 30.3 & 0.7 & 1.8 \\
\hline 155 & $\begin{array}{l}\text { TR- } \\
155\end{array}$ & 1986.9 & 34.8 & 27.3 & 43.5 & 193.4 & 312.0 & 16.2 & 33.4 & 0.7 & 1.9 \\
\hline 150 & $\begin{array}{l}\text { TR- } \\
150\end{array}$ & 1975.2 & 35.9 & 27.8 & 47.0 & 193.4 & 395.2 & 16.4 & 33.7 & 0.7 & 2.0 \\
\hline 145 & $\begin{array}{l}\text { TR- } \\
145\end{array}$ & 2111.7 & 33.8 & 26.2 & 42.4 & 184.2 & 547.3 & 17.7 & 36.5 & 0.8 & 2.0 \\
\hline 140 & $\begin{array}{l}\text { TR- } \\
140\end{array}$ & 2085.6 & 34.6 & 26.5 & 41.1 & 170.4 & 371.0 & 14.8 & 30.1 & 0.7 & 1.9 \\
\hline 135 & $\begin{array}{l}\text { TR- } \\
135\end{array}$ & 2104.8 & 36.9 & 29.0 & 44.2 & 184.5 & 334.6 & 15.4 & 31.5 & 0.7 & 2.0 \\
\hline
\end{tabular}




\begin{tabular}{|c|c|c|c|c|c|c|c|c|c|c|c|}
\hline 130 & $\begin{array}{l}\text { TR- } \\
130 \\
\end{array}$ & 2086.4 & 34.5 & 52.1 & 40.8 & 172.6 & 329.0 & 14.3 & 28.9 & 0.7 & 1.9 \\
\hline 125 & $\begin{array}{l}\text { TR- } \\
125\end{array}$ & 2121.9 & 39.2 & 28.0 & 44.8 & 179.3 & 303.0 & 15.1 & 30.8 & 0.7 & 1.9 \\
\hline 120 & $\begin{array}{l}\text { TR- } \\
120\end{array}$ & 2241.6 & 43.4 & 33.5 & 51.6 & 232.5 & 776.3 & 18.1 & 36.5 & 0.9 & 2.1 \\
\hline 115 & $\begin{array}{l}\text { TR- } \\
115\end{array}$ & 2255.2 & 40.1 & 34.5 & 46.5 & 197.0 & 343.5 & 16.4 & 34.4 & 0.7 & 2.0 \\
\hline 110 & $\begin{array}{l}\text { TR- } \\
110\end{array}$ & 2123.1 & 38.2 & 29.4 & 45.6 & 198.4 & 304.1 & 18.5 & 38.6 & 0.8 & 2.1 \\
\hline 105 & $\begin{array}{l}\text { TR- } \\
105\end{array}$ & 2172.2 & 39.6 & 28.4 & 46.6 & 202.8 & 376.7 & 18.7 & 38.7 & 0.8 & 2.1 \\
\hline 100 & $\begin{array}{l}\text { TR- } \\
100\end{array}$ & 2263.4 & 39.9 & 29.9 & 44.2 & 208.5 & 359.6 & 18.9 & 40.2 & 0.8 & 2.2 \\
\hline 95 & TR-95 & 2325.2 & 48.2 & 33.9 & 51.2 & 240.0 & 359.1 & 20.2 & 41.7 & 0.9 & 2.2 \\
\hline 90 & TR-90 & 2211.7 & 47.0 & 32.6 & 50.0 & 230.1 & 312.4 & 16.9 & 36.2 & 0.8 & 2.1 \\
\hline 85 & TR-85 & 2394.5 & 52.4 & 35.2 & 55.6 & 234.1 & 309.4 & 19.3 & 38.5 & 0.8 & 2.3 \\
\hline 80 & TR-80 & 2558.7 & 51.2 & 35.4 & 55.0 & 224.9 & 358.1 & 18.7 & 38.6 & 0.8 & 2.5 \\
\hline 75 & TR-75 & 2678.4 & 57.6 & 39.5 & 63.1 & 253.2 & 547.0 & 21.9 & 44.7 & 0.9 & 2.5 \\
\hline 70 & TR-70 & 2543.2 & 52.6 & 36.8 & 56.9 & 212.9 & 450.9 & 19.3 & 38.6 & 0.8 & 2.6 \\
\hline 65 & TR-65 & 2399.6 & 49.7 & 33.9 & 56.3 & 213.0 & 343.6 & 21.0 & 42.8 & 0.9 & 2.5 \\
\hline 60 & TR-60 & 2281.3 & 48.9 & 31.1 & 51.4 & 211.4 & 374.7 & 19.5 & 40.1 & 0.8 & 2.5 \\
\hline 55 & TR-55 & 2489.7 & 56.4 & 36.1 & 57.1 & 236.6 & 344.5 & 20.3 & 41.4 & 0.9 & 2.6 \\
\hline 50 & TR-50 & 2428.8 & 62.3 & 39.1 & 66.1 & 294.3 & 317.8 & 24.4 & 50.0 & 1.0 & 2.9 \\
\hline 45 & TR-45 & 3011.3 & 57.4 & 42.7 & 66.5 & 285.9 & 311.3 & 23.7 & 46.8 & 0.9 & 3.2 \\
\hline 40 & TR-40 & 3081.4 & 67.0 & 48.3 & 77.4 & 301.9 & 308.4 & 24.9 & 47.8 & 0.9 & 3.3 \\
\hline 35 & TR-35 & 2726.0 & 52.2 & 40.3 & 63.8 & 260.5 & 283.7 & 20.0 & 38.7 & 0.8 & 3.0 \\
\hline 30 & TR-30 & 3068.9 & 58.3 & 46.1 & 72.8 & 291.3 & 314.5 & 21.9 & 41.5 & 0.9 & 3.3 \\
\hline 25 & TR-25 & 3054.9 & 60.7 & 47.4 & 74.1 & 325.0 & 294.9 & 21.7 & 40.9 & 0.9 & 3.5 \\
\hline 20 & TR-20 & 2786.3 & 57.3 & 43.8 & 68.9 & 304.7 & 269.3 & 20.4 & 38.2 & 0.8 & 3.3 \\
\hline 15 & TR-15 & 3008.1 & 63.5 & 49.9 & 77.2 & 325.7 & 289.9 & 21.3 & 39.8 & 0.8 & 3.5 \\
\hline 10 & TR-10 & 2641.7 & 55.1 & 42.4 & 68.0 & 390.0 & 274.5 & 21.0 & 40.2 & 0.8 & 3.3 \\
\hline 5 & TR-5 & 2478.0 & 55.1 & 46.0 & 64.4 & 615.1 & 249.5 & 24.3 & 47.8 & 1.0 & 3.7 \\
\hline 0 & TR-0 & 1827.8 & 46.4 & 41.5 & 50.0 & 617.2 & 200.5 & 22.2 & 44.7 & 1.2 & 3.6 \\
\hline 0 & P-O & 118.3 & 6.5 & 15.1 & 4.4 & 209.5 & 15.7 & 13.3 & 29.2 & 1.0 & 4.1 \\
\hline-5 & $P-5$ & 21.4 & 3.4 & 10.3 & 0.5 & 132.0 & 6.9 & 3.6 & 0.8 & 0.1 & 6.6 \\
\hline-10 & P-10 & 44.4 & 7.1 & 17.9 & 0.8 & 162.3 & 3.3 & 5.9 & 1.6 & 0.2 & 2.9 \\
\hline-15 & P-15 & 39.8 & 13.1 & 18.0 & 1.1 & 148.8 & 1.1 & 4.9 & 1.3 & 0.1 & 3.5 \\
\hline-20 & P-20 & 74.5 & 9.1 & 42.8 & 2.0 & 111.2 & 0 & 11.7 & 4.3 & 0.4 & 5.6 \\
\hline-25 & P-25 & 117.4 & 7.6 & 32.2 & 3.0 & 126.6 & 3.9 & 8.7 & 4.0 & 0.3 & 6.5 \\
\hline-30 & $\mathrm{P}-30$ & 56.7 & 8.0 & 34.8 & 1.7 & 105.9 & 0 & 6.6 & 2.0 & 0.2 & 4.6 \\
\hline-35 & P-35 & 79.1 & 7.0 & 39.9 & 2.3 & 123.4 & 0 & 8.9 & 3.1 & 0.3 & 5.8 \\
\hline
\end{tabular}




\begin{tabular}{|l|c|c|c|c|c|c|c|c|c|c|c|}
\hline-40 & P-40 & 39.0 & 5.3 & 15.5 & 1.1 & 98.2 & 0 & 4.3 & 1.0 & 0.1 & 17.8 \\
\hline-45 & P-45 & NA & NA & NA & NA & NA & NA & NA & NA & NA & NA \\
\hline-50 & P-50 & 32.7 & 11.2 & 18.5 & 0.5 & 121.5 & 0.9 & 5.3 & 1.3 & 0.1 & 3.1 \\
\hline $\begin{array}{l}150 \\
-\end{array}$ & P-150 & NA & NA & NA & & NA & & NA & NA & NA & NA \\
\hline 250 & P-250 & NA & NA & NA & & NA & & NA & NA & NA & NA \\
\hline- & P-350 & NA & NA & NA & & NA & & NA & NA & NA & NA \\
\hline $\begin{array}{l}450 \\
450\end{array}$ & P-450 & NA & NA & NA & & NA & & NA & NA & NA & NA \\
\hline
\end{tabular}

